\title{
$\begin{array}{llllllllllllllllllllllll}\text { P } & R & Z & E & G & L & A & D & Z & A & C & H & O & D & N & I & O & P & O & M & O & R & S & K\end{array}$ ROCZNIK XXXI (LX) ROK 2016 ZESZYT 4
}

$\begin{array}{lllllllllllllll}\mathbf{S} & \mathbf{T} & \mathbf{U} & \mathbf{D} & \mathbf{I} & \mathbf{A} & \mathbf{I} & \mathbf{R} & \mathbf{O} & \mathbf{Z} & \mathbf{P} & \mathbf{R} & \mathbf{A} & \mathbf{W} & \mathbf{Y}\end{array}$

DARIUSZ ŁUKASIEWICZ*

\section{„BZiK Na PUNKCIE MieszKania”, CZyli MieszKanie I Jego otoczenie w Prusach w latach 1871-1918}

Słowa kluczowe: Prusy, mieszkalnictwo, industrializacja

Keywords: Prussia, housing sector, industrialisation

\section{Industrializacja, urbanizacja, migracje i wzrost cen mieszkań w miastach}

Własny dach nad głową w epoce industrializacji i urbanizacji w Prusach po 1871 roku był marzeniem dla wielu nieosiągalnym. Ówczesny Berlińczyk, Walter Benjamin, pisał, „że XIX stulecie jak żadne inne miało bzika na punkcie mieszkania”, tęskniło do mieszkania i mieszkania mu brakowało'. Adelheid Saldern wylicza liczne grupy mieszkańców, które miały wielkie problemy z dachem nad głową: chłopi, robotnicy rolni, dniówkowi, fabryczni, rzemieślnicy, ubożsi pracownicy umysłowi i niżsi urzędnicy². Na sposób zamieszkiwania wielki wpływ miało też rozszerzające się wraz z industrializacją i wielkim napływem ludności do miast zjawisko zubożenia niższych warstw miejskich, do którego - oprócz złych warunków mieszkaniowych - zaliczało się też nieodpowiednie wyżywienie i zaspokojenie innych potrzeb życiowych. Hans-Ulrich Wehler stwierdził słusznie, że

\footnotetext{
* Dr hab. Dariusz Łukasiewicz, prof. PAN, Instytut Historii PAN w Poznaniu, e-mail: dlukas@ man.poznan.pl.

${ }^{1}$ W. Benjamin, Pasaże, Kraków 2005, s. 250; H. Matzerath, Urbanisierung in Preußen 1815 1914, Stuttgart 1985, s. 241.

${ }^{2}$ A. von Saldern, Im Hause, zu Hause. Wohnen im Spannungsfeld von Gegebenheiten und Aneignungen, w: Geschichte des Wohnens, Bd. 3: 1800-1918. Das bürgerliche Zeitalter, hrsg. v. J. Reulecke, Stuttgart 1997, s. 147.
} 
dla klasy niższej i średniej mieszkanie było głównym, trudnym do rozwiązania problemem życiowym, a miasta stawały się polem narastających napięć społecznych i konfliktów.

XIX stulecie wytworzyło mieszczańskie kulturowe wyobrażenie przyjaznego domu, będącego miejscem odpoczynku i schronienia przed zagrożeniami świata, które stało się fundamentem dzisiejszych masowych wyobrażeń. Wówczas wszakże tylko niewielki odsetek owo przyjazne oparcie otrzymał, przytłaczająca większość dom traktowała jedynie jako sypialnię. Nowe, bogacące się elity mieszczańskie postrzegały jednak tę epokę z perspektywy własnych doświadczeń, jako „złoty wiek”, erę postępu, dobrobytu i rozwoju, równoznaczną i utożsamianą z wielkim rozkwitem kraju. Narastające w wielkich industrialnych miastach dysproporcje i masowa nędza nie były recypowane i rozumiane inaczej jak samozawinione albo godne ubolewania, ale nieuniknione. Dopiero stopniowo narastało rozumienie rzeczywistego znaczenia problemów mieszkalnictwa ${ }^{3}$.

Trzeba pamiętać, że industrializacja powiązana była i z innymi uwarunkowaniami rozwoju miast - z rozwojem handlu, komunikacji, co ułatwiało rozwój przestrzenny; w wypadku Berlina znaczącą rolę odgrywała też stołeczność. Przemysł stopniowo zaczął wychodzić poza miasto, na jego obrzeża. Masowa produkcja związana była z rynkiem masowej konsumpcji, a więc i rozrastającymi się sklepami, domami towarowymi, usługami. To była baza dla szybkiego, nieznanego dotąd „pęcznienia” miast. W 1867 roku w Prusach było tylko 536 miast powyżej 2000 mieszkańców, w 1910 - 1180. Podobnie z perspektywy Rzeszy. W 1871 roku miała ona tylko trzy miasta liczące powyżej 200 tys. mieszkańców: Berlin, Hamburg i Wrocław, w 1913 już 23. Wśród nich bezprzykładny był rozrost pruskiego Berlina z 826 tys. mieszkańców w 1871 roku do 2,07 mln w 1914, a Kolonii i Wrocławia do z górą 500 tys. Należy pamiętać, jak szybki był ten wzrost, na przykład liczba mieszkańców Essen wzrosła z 10 tys. w 1851 roku do 230 tys. w roku 1905. Wzrost był tak szybki, że przy przekształcaniu wsi w miasta i otrzymywaniu przez nie praw miejskich dochodziło do prawdziwych kuriozów. Hamborn nazywane było „największą wsią Prus”, a przekształcone zostało w miasto dopiero w 1911 roku, kiedy osiągnęło liczbę 102 tys. mieszkańców. Już na poziomie miast 50-tysięcznych takich przypadków było więcej. Procesy

\footnotetext{
${ }^{3}$ C. Zimmermann, Wohnen als sozialpolitische Herausforderung. Reformerisches Engagement und öffentliche Aufgaben, w: Geschichte des Wohnens..., s. 505, 518-519.
} 
urbanizacyjne dotyczyły w największym stopniu centralnych i zachodnich prowincji Prus. W okresie 1871-1918 przybyło tam 38 miast, a w zachodnich tylko dwa.

Wzrost miast w Prusach pochodził aż w 46,2\% z migracji, 41,6\% z nadwyżki urodzeń, w 12,2\% z włączeń do gminy ${ }^{4}$. Jednak w Prusach, inaczej niż w USA, bardzo szybki wzrost demograficzny opierał się nie na imigracji zewnętrznej, a na spadku śmiertelności i imigracji wewnętrznej. Zarówno na wschodzie, jak i na zachodzie Prus spadała liczba mieszkańców urodzonych w miejscu zamieszkania. W 1900 roku w Królewcu było to 40,9\% osób, w Poznaniu 41,3\%, w Bydgoszczy 29,8\%, w Kolonii 51\%, w Düsseldorfie 44,9\%, w Essen 39\%. W 1907 roku połowa mieszkańców Niemiec urodziła się w innej prowincji niż mieszkała w chwili badania. Jak wiadomo, wschodnie prowincje Prus należały do uboższych i stamtąd właśnie emigracja do uprzemysłowionych zachodnich Niemiec była znaczna. Jak jednak wskazują niektóre badania (np. emigracja z Prus Wschodnich do Zagłębia Ruhry), emigrowali nie najbiedniejsi, ale średniozamożni chłopi, którzy szukali poprawy sytuacji, a nie ratunku przed całkowitą nędzą. Żyjące w biedzie masy robotników rolnych często traciły zdolność zmiany swojej sytuacji i jakąkolwiek społeczną mobilność. Równocześnie miała miejsce lokalna migracja ze wsi do miast, także w prowincjach wschodnich.

Napływu ludności spoza granic nie było, przeciwnie, Prusy, które niezagospodarowanych obszarów na sprzedaż nie miały, traciły obywateli przez emigrację. W latach 1885-1895 emigracja zamorska z całych Niemiec wynosiła rocznie 80-97 tys. osób. Tak więc nie było imigracji do Prus, a pod koniec XIX zaczął się też spadek liczby urodzeń, aż o 1/3 w okresie 1880-1913. Oznacza to wzrost demograficzny wynikający z urodzeń przed 1900 rokiem i spadek później, ale też na pewno wzrost stosowania antykoncepcji. Wzrósł też poziom wyżywienia, medycyny, zdrowotności, służby zdrowia. Alarmy o stanie industrialnych miast były jednak zasadne. Wprawdzie chłopi mieli dawniej lepszy dostęp do źródeł pożywienia, ale z kolei dotykały ich dramatyczne w skutkach klęski głodu, które od połowy XIX wieku zaczęły ustępować.

\footnotetext{
${ }^{4}$ H. Matzerath, Urbanisierung in Preußen 1815-1914..., s. 242, 250, 267; H.-U. Wehler, Deutsche Gesellschaftsgeschichte, Bd. 3: 1849-1914, München 1995, s. 511-514.
} 


\section{Wohnungsfrage}

Popyt na mieszkania, rosnący w końcu XIX wieku w wyniku wzrostu liczby mieszkańców, powodował z jednej strony podwyższenie czynszów, z drugiej wykorzystanie na mieszkania wszystkich możliwych kątów, dachów, strychów, nawet przestrzeń pod schodami była wykorzystana przez służbę do spania. Domy stawały się też coraz wyższe, co powodowało oszczędności na cenie gruntu 5 .

Problem mieszkaniowy (Wohnungsfrage) narastał, jednak w latach 18501880 był jeszcze „niedoświetlony” i nie bardzo wiedziano, co z nim zrobić, bo nikt nie potrafił wyjść albo poza koncepcje liberalne, albo paternalistyczne ${ }^{6}$. Już w pierwszym dziesięcioleciu XIX wieku ubóstwo i życie miejskie było krytykowane. Handlarz książek, po odwiedzeniu przemysłowego Wuppertalu, orzekł, że industrializacja to ,grób naszego charakteru, naszych obyczajów i naszej siły”7. Historycy liberalni czasem bagatelizują rozmiary ówczesnych problemów mieszkaniowych uznając, że sytuacja nie była taka zła, jednak jest to manipulowanie statystykami - prawdę mówiąc - wręcz groteskowe. Uznawanie za stan zadowalający albo choćby akceptowalny masowe i powszechne mieszkania jednoizbowe dla całych rodzin, z rodzicami śpiącymi razem z dziećmi w jednym łóżku, jest poważną aberracją. W rzeczywistości sytuacja uległa normalizacji dopiero po drugiej wojnie światowej, przez rozpoczęcie ogromnych programów budownictwa socjalnego, w których standardem było mieszkanie wielopokojowe z izbami funkcjonalnie wzorowanymi na mieszkaniu mieszczańskim (tj. salon, sypialnia, pokój dziecięcy), łazienką i toaletą. Mobilizujące do pracy różnice między bogactwem i biedą nie zniknęły, ale straciły swoje patologiczne rozmiary ${ }^{8}$.

Historyk Clemens Zimmermann zauważy19 ${ }^{9}$, że w epoce przednowoczesnej obszarem troski Kościoła i państwa były zdrowie i bieda, ale mieszkania już nie.

${ }^{5}$ H.-U. Wehler, Deutsche Gesellschaftsgeschichte..., s. 515; U. Frevert, Krankheit als politisches Problem. Soziale Unterschichten in Preußen zwischen medizinischer Polizei und staatlicher Sozialversicherung, Göttingen 1984, s. 185; R.H. Tilly, Vom Zollverein zum Industriestaat. Die wirtschaftlich-soziale Entwicklung Deutschlands 1834 bis 1914, München 1990, s. 130-131.

${ }^{6}$ Tamże, s. 149.

${ }^{7}$ J. Reulecke, Die Mobilisierung der „,Kräfte und Kapitale“ der Wandel der Lebensverhältnisse im Gefolge von Industrialisierung und Verstadterung, w: Geschichte des Wohnens..., s. 18-19.

${ }^{8}$ C. Wischermann, Wohnen in Hamburg vor dem Ersten Weltkrieg, Münster 1983, s. 130-250.

${ }^{9}$ C. Zimmermann, Wohnen als sozialpolitische Herausforderung. Reformerisches Engagement und öffentliche Aufgaben, w: Geschichte des Wohnens..., s. 505, 518-519; G.A. Ritter, Der Sozialstaat. Etstehung und Entwicklung im internationalen Verleich, München 1991, s. 62-63. 
W tym zakresie zmiany przyniosła nowoczesność i to właściwie dopiero w XX wieku. Opieka socjalna przed pierwszą wojną światową była bardzo dyskryminująca, wykluczająca i dokonująca społecznej segregacji. O żadnej równości wobec prawa nie było mowy. Trzeba to jednak uzupełnić o kluczowe stwierdzenie, że w epoce nowożytnej strukturalnie miejsce państwa zajmował szlachcic na wsi albo mistrz cechowy w mieście. Także chaty chłopskie w świecie feudalnym nie kosztowały zbyt wiele, gdy drewno pochodziło z pańskiego lasu i z szybami i kominem był nawet problem, a robili je sami chłopi. Oczywiście występował także problem dziedziczenia i liczniejszego potomstwa, ale system „od biedy” działał. Z kolei rzemieślnik uczniów i czeladników przyjmował w mieście pod swój dach bezpłatnie, chociaż oznaczało to dla nich całkowity brak prywatności i niemożność założenia rodziny.

Tak więc pomoc Kościoła i państwa nie była konieczna, a i tak szpitale średniowieczne były też przytułkami dla bezdomnych; jałmużny dla biednych w tych czasach były dosyć hojne. Wohnungsfrage jako przedmiot debaty publicznej pojawiło się dopiero w XIX wieku, a w rzeczywistości nasilało od połowy i szczególnie pod koniec stulecia, wraz z przyśpieszeniem migracji do miast. Pojawiły się pojęcia Wohnungsproblem $i$ Wohnungsnot, jako część szerszej kategorii - Sozial Frage.

Liberalny model myślenia oznaczał doktrynerskie i niepraktyczne myślenie w kategoriach rynkowych oraz ścisłe wiązanie rozwoju mieszkalnictwa z produkcją mieszkań i rynkiem kapitałowym, ideowo odrzucając ingerencję państwa czy komunalną. Z powodu nacisku pozbawionych perspektyw mieszkaniowych robotników nasilała się w tym czasie polityzacja problemu mieszkaniowego i próby poprawy sytuacji przez interwencję państwa na rynku mieszkań. Socjalny konserwatysta i uczony, profesor Gustaw von Schmoller, w 1890 roku wskazywał, że właśnie „wrzód nierozwiązanej kwestii mieszkaniowej sprowadzający warunki życia robotników do poziomu barbarzyństwa i zezwierzeńcenia w szybko rosnących wielkich miastach może stać się przyczyną rewolucji”" ${ }^{10}$. Generalnie powstanie państwa dobrobytu było niezbędne w obliczu głębokich przemian społecznych - industrializacji, wielkich migracji, sekularyzacji, przemian

${ }^{10}$ Ostrzegał on przed „,socialen Revolutionen, die kommen müssen, wen wir nicht aufhören die unteren Klassen in unseren Großstädten durch ihre Wohnungsverhältnisse zu Barbaren zu tierischem Dasein herabzudrücken”, za: B. Fuhrmann, W. Meteling, B. Rajkay, M. Weipert, Geschichte des Wohnens von Mittelalter bis heute, Darmstadt 2008, s. 101. Zob. także T. Nipperdey, Deutsche Geschichte 1866-1918, München 1991, s. 142; C.J. Fuchs, Wohnungsfrage, w: Die Entwicklung der deutschen Volkswirtschaftslehre im 19 Jahrhundert, Leipzig 1908, T. 1, s. 1-2. 
mentalności w społeczeństwie masowym, politycznej mobilizacji mas ${ }^{11}$. Powstały liczne działające w Prusach towarzystwa i organizacje (Verein für Sozialpolitik) podejmujące refleksje i pierwsze działania dla zaradzenia złej i niebezpiecznej, również dla klas wyższych, sytuacji w dziedzinie mieszkalnictwa. Zajmowały się one przede wszystkim sytuacją warstwy robotniczej. Refleksje i projekty reform często miały konserwatywny charakter i niezbyt racjonalnie wspierały idee drogiego budownictwa indywidualnego dla robotników, co wynikało z przekonania o demolującym więzi środowiskowe i wspólnotowe, niehigienicznym oraz demoralizującym charakterze Mietskaserne ${ }^{12}$.

\section{Masowe wynajmowanie mieszkań}

W miastach mieszkania przede wszystkim wynajmowano, bo zakup był za drogi. Utrzymanie mieszkania było problemem nawet dla niższych pracowników umysłowych i urzędników ${ }^{13}$. Najdroższe, jeżeli chodzi o wysokość czynszu w stosunku do metrażu, i najpopularniejsze były, tak samo jak dzisiaj, mieszkania jednopokojowe, bo był na nie największy popyt - a więc najbiedniejsi płacili najwięcej. Trzeba też pamiętać, że aby zamortyzować cenę gruntu, kamienice stawały się coraz wyższe. Widać to po gęstości zaludnienia w miastach. W zachodnich prowincjach zaludnienie wzrosło do 1224 mieszkańców na km² w 1910 roku z 683 w roku 1885 . W prowincjach wschodnich w tych samych przedziałach czasowych - z 349 na 487. Liczba mieszkańców przypadających na dom w Prusach w latach 1875-1910 wzrosła z 8,5 na 10. W tym samym czasie w miastach prowincji wschodnich z 14 na 16,5, a prowincji zachodnich - z 10,1 na 13. Coraz wyższe były przede wszystkim czynszówki dla biedoty. 30\% mieszkań stanowiły też oficyny (dane: Berlin, Charlottenburg, Magdeburg, Poznań). Wysokie kamienice, bez wind, dla biedoty mieszkającej na wyższych piętrach były udręką (np. noszenie wody ze studni przez kobiety). Upowszechnianie wodociągów, kanalizacji,

${ }^{11}$ G.A. Ritter, Der Sozialstaat..., s. 64.

${ }^{12}$ C.J. Fuchs, Wohnungsfrage..., s. 18-19.

${ }^{13}$ C. Zimmermann, Wohnen als sozialpolitische Herausforderung..., s. 505, 518-519, 556; B. Fuhrmann, W. Meteling, B. Rajkay, M. Weipert, Geschichte des Wohnens von Mittelalter..., s. 103; J. Kuczynski, Geschichte des Alltags des deutschen Volkes, Bd. 4, Berlin 1982, s. 175-177; P.H. Feist, Geschichte der deutschen Kunst 1848-1890, Leipzig 1987, s. 257-258; T. Nipperdey, Deutsche Geschichte 1866-1918..., s. 136, 142-143; E. Makowski, Ruch robotniczy w Wielkopolsce. Zarys dziejów do roku 1981, Poznań 1984, s. 33-34; H. Matzerath, Urbanisierung in Preußen $1815-1914 \ldots$, s. 302-303, 310. 
gazu i wind, stopniowo te dolegliwości zniwelowało. W latach 1861-1871 liczba berlińskich domów mieszkalnych wyższych niż 4 piętra wzrosła z 3785 na 14777 , natomiast z 20 tys. w 1875 roku - do 200 tys. w roku 1911. Szczególnie duża koncentracja Mietskasern występowała w Berlinie, gdzie w 1900 roku 1/6 mieszkań znajdowała się w dużych kamienicach liczących ponad 30 mieszkań. Mniejsze kamienice częściej występowały na wschodzie - od Wrocławia do Królewca.

Grupy społeczne i zawodowe coraz częściej skupiały się przy jednej ulicy, w jednym kwartale, co sprawiało, że kamienice stały się bardziej jednorodne społecznie niż kiedyś i przy pewnym poziomie zamożności coraz bardziej liczył się „dobry adres”.

Prawie wszystkie mieszkania przeznaczone były na wynajem, co wynikało z dysproporcji między zarobkami i ceną zakupu własnego lokum. Już od 1820 roku 75\% wzrostu rocznego ludności Berlina stanowiła migracja, za czym mieszkalnictwo zupełnie nie nadążało, a więc ceny rosły. Berlin był pod tym względem miastem zupełnie wyjątkowym w porównaniu do Londynu i Paryża, które były wielkie już na początku XIX wieku i gdzie nie było aż takiego szalonego tempa wzrostu tkanki miejskiej. Już w końcu XVIII wieku 66-75\% mieszkań w Berlinie była wynajmowana, ale w 1871 roku wskaźnik ten wzrósł do 95\%, co oznaczało narastanie ilości masy robotniczej oraz klas średnich. Zamożniejsi również bowiem poprzestawali na wynajmie, nawet średniozamożni urzędnicy w ich wypadku były to większe wielopokojowe mieszkania w „porządnych” kamienicach. jeśli chodzi o ludność uboższą, wynajmowane mieszkania były małe i bardzo często przepełnione. W 1871 roku przepełnionych było 23 tys. mieszkań berlińskich, czyli 13\%, prawie wszystkie jednopokojowe. W rzeczywistości jednak było ich o wiele więcej, jedynie urzędowe normy były bardzo niskie. Po 1871 roku pod Berlinem zaczęto też tworzyć osiedle baraków dla robotników, czyli właściwie slumsy. Ten fatalny stan rzeczy przez zamożnych mieszczan był oczywiście bardzo krytykowany - jako kryminogenny, prowadzący do braku zakorzenienia, rozpadu więzi rodzinnych i demoralizujący. Winą obciążano samych robotników, zarzucając im stereotypowo lenistwo, pijaństwo i rozpustę oraz hazard i marnotrawstwo.

Bardzo powoli spadała liczba mieszkań jednoizbowych. W 1875 roku w Berlinie wynosiła ona 53\%,w 1911 roku - 44\%. Z kolei udział mieszkań większych dwuizbowych wzrósł z 25 na 31\%, a większych - z 22 na 25\%. Przestrzeń mieszkalna na osobę pod koniec wieku wynosiła w dużych miastach $10-12 \mathrm{~m}^{2}$, a sto lat 
później - już $39^{14}$. Cały czas problemem byli najemcy samego łóżka - Schlafgängerzy, których w Polsce zwano najemcami „ciepłego łóżka”, śpiący w tym samym, wygrzanym przez poprzednika łóżku. W 1880 roku w Berlinie było ich 59 tys., w 1885 - 85 tys., w 1890 - 95 tys. ${ }^{15}$ Nie inaczej było w Szczecinie, gdzie nazywano ich także Schlafleute - tutaj było ich w 1880 roku 2000, prawie wyłącznie mężczyzn ${ }^{16}$.

Nieustanne były przeprowadzki z powodu zmian pracy, niszczące stabilność rodziny i jej umocowanie w środowisku sąsiedzkim kamienicy. W Berlinie przeprowadzki obejmowały rocznie aż 38\% lokali w 1871 roku i $43 \%$ lokali w roku 1872. W 1900 roku sytuacja nadal była zła - na 1,9 mln mieszkańców odbyło się 715 tys. przeprowadzek. W Essen około 1900 roku 50\% mieszkańców zmieniała miejsce zamieszkania w ciągu dwóch lat ${ }^{17}$.

\section{Infrastruktura miejska, komunikacja i innowacje techniczne}

W końcowych dziesięcioleciach XIX wieku pojawiła się zupełnie nowa, nieznana wcześniej infrastruktura miejska, zmieniająca jakość życia, najpierw najzamożniejszych, szybko jednak ulegając upowszechnieniu i docierając do robotników. Już wcześniej jednak stopniowy rozwój kolei i komunikacji tramwajowej umożliwił i przyśpieszył przestrzenny rozwój miast. W całej Europie, nie tylko w Berlinie, rozbudowywano obwodnice (Ringi), upowszechnianie żelazobetonu zaś ułatwiało budownictwo. Miasta rozprzestrzeniały się według schematów gwiaździstych czy promienistych z koncentrycznymi placami ozdobionymi monumentami lub na podstawie siatk $\mathrm{i}^{18}$.

Berlińczyk Walter Benjamin wspominał wiek XIX, że kojarzy mu się nie z operetkami Offenbacha, ani muzyką podczas parad wojskowych: „Nie, słyszę

${ }^{14}$ B. Fuhrmann, W. Meteling, B. Rajkay, M. Weipert, Geschichte des Wohnens von Mittelalter..., s. 121, 128-129; H. Matzerath, Urbanisierung in Preußen 1815-1914..., s. 279.

${ }^{15}$ Tamże, s. 215; B. Baranowski, Wyposażenie wnętrz, w: Historia kultury materialnej Polski, t. 6, red. B. Baranowski, Wrocław 1979, s. 431.

${ }^{16}$ L. Turek-Kwiatkowska, Życie codzienne w Szczecinie w latach 1800-1939, Szczecin 2012, s. 40 .

${ }^{17}$ B. Fuhrmann, W. Meteling, B. Rajkay, M. Weipert, Geschichte des Wohnens von Mittelalter..., s. 104; J. Wietog, Der Wohnungsstandard der Unterschichten in Berlin, w: Arbeiterexistenz im 19. Jahrhundert. Lebensstandard und Lebensgestaltung deutscher Arbeiter und Handwerker, hrsg. v. W. Conze, U. Engelhardt, Stuttgart 1981, s. 114-129; J. Kuczynski, Geschichte des Alltags..., s. 201-202, 210; T. Nipperdey, Deutsche Geschichte 1866-1918..., s. 144-145, 210.

${ }^{18}$ P.H. Feist, Geschichte der deutschen Kunst..., s. 260-261, 264-265. 
krótki łoskot węgla, który z blaszanego pojemnika wpada do żelaznego pieca, stłumiony wybuch z jakim zapala się żarnik lampy gazowej i pobrzękiwanie jej klosza na mosiężnej podkładce, gdy ulicą przejeżdża wóz”"19. To znany nam dobrze język i metaforyka wielbiącego, a w każdym razie zafascynowanego postępem technicznym i nowoczesnością wieku pary i elektryczności, człowieka. W Berlinie, Szczecinie, Poznaniu czy Wrocławiu już ok. 1900 roku podniosła się jakość mieszkań z powodu sukcesywnego upowszechniania wodociągów, skanalizowanych toalet z syfonem dla poszczególnych mieszkań (a nie w pionie, albo na piętrze) oraz możliwości ogrzewania mieszkań. Na Śląsku, a jeszcze bardziej w Zagłębiu Ruhry, a także w kraju Saary na zachodzie Prus, było jednak zdecydowanie lepiej ${ }^{20}$.

Od połowy lat 70. XIX wieku do pierwszej wojny światowej część miast pruskich, a 2/3 miast w Niemczech, miało już gazownie, chociaż lampy gazowe w mieszkaniach pojawiły się już w latach 60 . Po 1900 roku w mieszkaniach szybko upowszechniało się oświetlenie elektryczne, po 1880 - centralne ogrzewanie i kaloryfery, początkowo tylko na korytarzu, potem w mieszkaniach. Podobnie na szeroką skalę rozwijały się wodociągi i kanalizacja. Prusy przodują, ale gdzie indziej prace przebiegają w podobnym czasie. Około 1900 roku w lepszych domach pojawiło się WC w poszczególnych mieszkaniach, ale w czynszówkach toaleta ciągle była tylko jedna na całe piętro ${ }^{21}$.

Na każdym podwórku znajdowały się cementowane kloaki i szamba, opróżniane 2-3 razy do roku. Początkowo też woda do spłukiwania ulic i chodników oraz klozetów spływała przy braku osobnej kanalizacji toalet do otwartych rynien i ogólnych kanałów. Dopiero prace w zakresie higieny i stosunków sanitarnych oraz medycyny społecznej, szczególnie Ślązaka z Wrocławia - Rudolfa Virchowa i Niemca - wolsztynianina z Wielkopolski Roberta Kocha, doprowadziły do pozytywnych zmian. Szczególne zasługi miało Deutsche Verein für Gesundheitspflege (1873), zajmujące się m.in. badaniami nad leczeniem tyfusu i znaczeniem wody pitnej. W Berlinie w latach 1885/1886 90\% parceli miało już nowoczesną

${ }^{19}$ W. Benjamin, Berlińskie dzieciństwo na przełomie wieków, Warszawa 2010, s. 13.

${ }^{20}$ C. Zimmermann, Wohnen als sozialpolitische Herausforderung..., s. 520-524; B. Fuhrmann, W. Meteling, B. Rajkay, M. Weipert, Geschichte des Wohnens von Mittelalter..., s. 124-126; L. Mumford, Die Stadt. Geschichte und Ausblick, Köln 1963, s. 549-551, 554-555; E. Włodarczyk, Rozwój przestrzenny i demograficzny miasta, w: Dzieje Szczecina 1806-1945, red. B. Wachowiak, Szczecin 1994, s. 290-294.

${ }^{21}$ T. Nipperdey, Deutsche Geschichte 1866-1918..., s. 140; G. Vigarello, Historia zdrowia i choroby, Warszawa 1997, s. 222. 
kanalizację. W miastach, jako zauważalne $\mathrm{z}$ daleka elementy nowoczesnego miejskiego pejzażu, pojawiły się wieże ciśnień, a w okresie 1850-1880 liczba zachorowań na tyfus znacznie spadła ${ }^{22}$.

Przedstawimy rozwój infrastruktury na przykładzie średniej wielkości miasta w prowincji wschodniej. W Szczecinie komunalna infrastruktura rozwijała się już w I połowie XIX wieku, od gazowni powstałej w 1848 roku poczynając. Gaz wykorzystywano do oświetlenia mieszkań oraz ulic. Tworząc sieć kanalizacyjną i wodociągową (1865 r.) władze korzystały z doświadczeń Berlina, Essen i Halle. Wodociąg miejski zaopatrywał mieszkańców w filtrowaną wodę rzeczną. Wieża ciśnień oddana została do użytku w 1882 roku; podłączonych do sieci było wówczas 1530 budynków, a więc ok. 70\%. Koszty utrzymania gazowni i wodociągów pochłaniały rocznie aż $20 \%$ wydatków miasta.

Wszystkie przedsięwzięcia miały charakter miejski, a nie prywatny, i bywały nierzadko wspierane z budżetu państwa. Tak było w 1878 roku, kiedy państwo przejęło finansowanie kontynuacji budowy wodociągu. W latach 80 . sieć wodociągowa liczyła $5 \mathrm{~km}$, w 1897 roku - 94,6 km, a do 1910 roku rozrosła się do $193,5 \mathrm{~km}$. Zużycie wody wzrosło w mieście z 3236 tys. m³ w 1885 roku do 5424 w roku 1910. Zużycie gazu z $3973 \mathrm{~m}^{3}$ w roku 1880 - do 12728 w 1910 roku. Ścieki odprowadzano bez oczyszczania do Odry, a kanalizacja z lat 90. była prymitywna. Kanałów ściekowych (murowanych, betonowych, z rur glinianych i najstarszych - drewnianych) było łącznie $64,3 \mathrm{~km}$. Oczyszczalnię ścieków Szczecin otrzymał na początku XX wieku. W 1912 roku sieć kanalizacyjna Szczecina rozrosła się do $136 \mathrm{~km}$, dla porównania - wrocławska miała $343 \mathrm{~km}$, a gdańska $110 \mathrm{~km}$. Pierwsza elektrownia szczecińska powstała w roku 1890, a do wybuchu wojny oddano do użytku dwie kolejne. Dzięki temu w 1897 roku rozpoczęto stałą eksploatację dwóch pierwszych linii tramwajowych ${ }^{23}$, konsultując rozwiązania we Wrocławiu. Tramwaj elektryczny zasadniczo zmieniał sytuację komunikacyjną miasta, skracając czas dojazdów mieszkańców do pracy, chociaż bilety dla robotników były zbyt drogie.

W Prusach, po wodociągach i kanalizacji, pojawiły się elektrownie i instalacje techniczne. Punktem wyjścia dla tej rewolucji było wynalezienie dynama przez Wernera von Siemensa. W latach 80 . powstawały pierwsze elektrownie

${ }^{22}$ B. Fuhrmann, W. Meteling, B. Rajkay, M. Weipert, Geschichte des Wohnens von Mittelalter..., s. 101-107.

${ }^{23}$ E. Włodarczyk, Rozwój przestrzenny i demograficzny miasta..., s. 299-305; B. Fuhrmann, W. Meteling, B. Rajkay, M. Weipert, Geschichte des Wohnens von Mittelalter..., s. 106. 
- w 1887 roku w Elberfeld, w 1888 w Barmen, w 1889 w Królewcu, w 1890 w Hanowerze, następnie w Berlinie i Hamburgu. W 1908 roku już 2/3 średnich i dużych miast w Prusach miało elektrownie. W przeciwieństwie do gazowni były one w większości komunalne, chociaż $\mathrm{z}$ czasem powstawały też wielkie elektrownie prywatne, które sprzedawały miastom prąd.

Największy popyt na energię elektryczną występował ze strony rozwijającego się przemysłu i komunikacji tramwajowej. Pierwszy tramwaj elektryczny pojawił się w Berlinie w 1879 roku, ale stała linia powstała w tym mieście dzięki Wernerowi von Siemensowi w 1881 roku (w Wiedniu np. w 1883 r. $)^{24}$. Pamiętać trzeba jednak, że w zakresie komunikacji miejskiej ważną rolę odgrywały dorożki, tramwaje konne (Charlottenburg 1865), kolejka miejska z parowozami (Berlin 1886), w latach 90. wyparta na szerszą skalę przez tramwaje elektryczne. Kolej miejska w Berlinie była rozbudowywana od 1908 roku o metro. Za komunikację miejską odpowiadały władze komunalne, a indywidualna komunikacja automobilowa dopiero raczkowała ${ }^{25}$.

Wprawdzie dotyczyło to tylko elit, jednak w mieszkaniach coraz częściej pojawiały się łazienki i wanny z napuszczaną z kranu wodą i odpływem oraz WC z odpływem wody, rozwiązując problemy higieniczne, które wcześniej były dosyć kłopotliwe ${ }^{26}$. Na wyposażeniu mieszkań z wolna pojawiał się też telefon. Benjamin komentował: „Niewielu korzystających dzisiaj z telefonu wie jakie spustoszenie spowodowało kiedyś jego pojawienie się na łonie rodziny. Jazgot jaki wydawał między drugą a czwartą po południu, gdy jakiś kolega szkolny znów zażyczył sobie rozmowy ze mną był sygnałem alarmowym, który zakłócał nie tylko sjestę moich rodziców, lecz całą epokę dziejów powszechnych, w której centrum się jej oddawali. Sprzeczki z urzędnikami były regułą, nie mówiąc już o pogróżkach i inwektywach Ojca pod adresem biura skarg i zażaleń. Jednak prawdziwe orgie wyczyniał on z korbką, którą obracał zapamiętale przez całe minuty (...). W tym okresie telefon wisiał odstawiony na bok i wykluczony między skrzynią na brudną bieliznę, a gazomierzem w rogu tylnego korytarza, skąd jego Jazgot jeszcze wzmagał grozę berlińskiego mieszkania”"27. W końcu XIX wieku

\footnotetext{
${ }^{24}$ W. Benjamin, Berlińskie dzieciństwo..., s. 10; tenże, Pasaże..., s. 108-111; H. Matzerath, Urbanisierung in Preußen 1815-1914..., s. 336.

${ }^{25}$ H. Matzerath, Urbanisierung in Preußen 1815-1914..., s. 286-287.

${ }^{26}$ Tamże, s. 184; C. Zimmermann, Wohnen als sozialpolitische Herausforderung..., s. 624625.

${ }^{27}$ W. Benjamin, Berlińskie dzieciństwo..., s. 10; tenże, Pasaże..., s. 40-41.
} 
w kuchniach używano już nierzadko gazowych pieców, chociaż były niedoskonałe - gaz ulatniał się, dochodziło do eksplozji i pożarów. Kuchnia elektryczna oraz centralne ogrzewanie pojawiły się pod koniec XIX wieku, ale stanowiły jeszcze wielką rzadkość. W mieszkaniach i na ulicach w II połowie XIX wieku stosowano już powszechnie oświetlenie gazowe. Początki oświetlenia elektrycznego przypadają na schyłek XIX wieku, ale jego upowszechnienie nastąpiło dopiero w wieku XX. Pierwsze żarówki były bardzo nietrwałe, ich żywotność nie przekraczała 150 godzin (dzisiaj - od 2000 do 100000 godzin). W 1900 roku został opatentowany odkurzacz, chociaż jego upowszechnienie nastąpiło dużo później, przy czym pierwsze modele były ogromne, wielkości obecnej lodówki. W interesującym nas okresie odkurzanie spadało na panią domu, jej córkę albo służącą. Od dawna znane były żelazka z duszą, jednak w XIX wieku pojawiły się często wybuchające żelazka gazowe, a na koniec stulecia elektryczne, które upowszechniły się w XX wieku. Ważnym elementem wyposażenia domowego była maszyna do szycia Singera, jako że znacznie więcej rzeczy niż dzisiaj naprawiano, cerowano i szyto. Była to epoka rewolucji domowej, jeżeli chodzi o ułatwienia i usprawnienia spraw codziennych, tak też było z maszyną do szycia, która oznaczała odejście od żmudnego szycia ręcznego. Sam Karol Marks wskazał ją w $\mathrm{Ka}$ pitale jako przykład rewolucji technicznej. Jej konstrukcja powiązana była z rozwojem masowego przemysłu maszynowego. Maszyna do szycia skonstruowana została w USA, jednak w Niemczech i Prusach pojawiła się już w połowie XIX wieku. Brockhaus z 1854 roku informował, że maszyna do szycia, to „najnowszy amerykański wynalazek, ulepszony i wielorako stosowany w Niemczech" ${ }^{28}$. Produkcja niemieckich maszyn do szycia ruszyła już w latach 60. XIX wieku i był to jedyny kraj przed pierwszą wojną światową produkujący podobną jak USA ilość tych maszyn. W 1890 roku ich roczna produkcja w Niemczech stanowiła 1/3 produkcji światowej, czyli 500 tys. sztuk, zaś w 1907 roku już 1,1 mln sztuk. Było to urządzenie pożądane, ale drogie. W latach 50-60. maszyna kosztowała 200-300 marek, potem staniała o połowę, ale i tak dla wielu była niedostępna. Wprowadzono więc system sprzedaży ratalnej ${ }^{29}$. Maszyna do szycia, jak i inne urządzenia techniczne, ułatwiała życie gospodyń domowych i ograniczała wydatki na krawca i szwaczkę. Obok gry na pianinie zaczęto uczyć córki szycia na maszynie, bo

\footnotetext{
${ }^{28} \mathrm{~K}$. Hausen, Postep techniczny a praca kobiet $w$ XIX w. Maszyna do szycia w świetle historii społecznej, w: tejże, Porządek ptci. Studia historyczne, Warszawa 2010, s. 150-177.

${ }^{29}$ Tamże, s. $159-161$.
} 
miało to być rozwiązaniem problemu zdobycia środków utrzymania na przykład na wypadek śmierci męża. Wiele kobiet $\mathrm{w}$ domu pracowało dorywczo, zatrudniało się też w przemyśle odzieżowym, jednak otrzymywane wynagrodzenie było bardzo niskie. Na skalę zjawiska wskazywał już w 1870 roku Gustaw Schmoller, a berlińskie czasopismo kobiece „Bazar” reklamowało ją: „Któż więc może przeczyć temu, że poprzez zaprowadzenie maszyny do szycia w rodzinie rozwiązał się problem i praca przestała być ciężarem, lecz jawi się jako przyjemność i miły sposób spędzania czasu" ${ }^{\prime 30}$.

Wszystkie ważniejsze innowacje upowszechniały się w Niemczech najszybciej na świecie, ponieważ ich państwowe uniwersytety wiodły prym w rewolucji naukowo-technicznej we wszystkich dziedzinach: chemii, elektryczności, komunikacji, optyce. Elektryczność pojawiła się początkowo tylko w mieszkaniach najbogatszych, a koszty energii dostosowane były jedynie do ich kieszeni. Cały czas prowadzone były jednak starania, aby przy komunalnej własności elektrowni, zasięg użytkowania energii elektrycznej nie miał charakteru klasowego ${ }^{31}$.

\section{Mieszkania zakładowe, spóldzielnie i dysproporcje w różnych grupach społecznych}

$\mathrm{W}$ jednych kwestiach następował regres, w innych postęp. 22\% robotników na Śląsku i w Ruhrze mieszkało w mieszkaniach zakładowych, wśród pracowników Kruppa 25\%, wśród górników 15-20\% mieszkań było wynajmowanych. Wprawdzie w byle jak zbudowanych kamienicach, ale nierzadko w mieszkaniach dwupokojowych albo nawet w małych domkach, właśnie z dwoma izbami mieszkalnymi. Rola mieszkań zakładowych była całkiem znacząca, rósł także ich standard. W 1900 roku w Essen 12\% robotników mieszkało w mieszkaniach zakładowych. Po 1900 roku miały one już często kanalizację, toalety, pralnie, piwnice i strychy. Powstawały całe zakładowe osiedla jak „Altenhof” Kruppa z 1892/1893 roku, „Hellerau” z lat 1909/1910. Kolonia „Merck” na obrzeżu Darmstadt obejmowała 200 domków, z których każdy miał dwa pokoje i kuchnięę2.

${ }^{30}$ Tamże, s. 162.

${ }^{31}$ W. Benjamin, Berlińskie dzieciństwo..., s. 10; tenże, Pasaże..., s. 108-111.

${ }^{32}$ C. Zimmermann, Wohnen als sozialpolitische Herausforderung..., s. 580-585; T. Nipperdey, Deutsche Geschichte 1866-1918..., s. 149; C.J. Fuchs, Wohnungsfrage..., s. 4; H. Matzerath, Urbanisierung in Preußen 1815-1914..., s. 297-299. 
Pierwsze towarzystwa budowlane (Baugenossenschaften, Baugesellschaften) powstały w Hamburgu (1862) i Karlsruhe (1870). Były to de facto spółdzielnie zwykłych pracowników, a więc niedysponujące większymi środkami na inwestycje. Musiały więc brać kredyty na hipotekę domów budowanych zwykle na gruntach gminy. Kredyty udzielane były w znacznym stopniu przez towarzystwa ubezpieczeniowe. Spółdzielnie rozwinęły się po roku 1900 i w 1914 roku istniały już w Niemczech 1402 towarzystwa ze 105 tys. wybudowanych mieszkań. Było to uzupełnienie rynku mieszkaniowego, ale o sporym znaczeniu. Towarzystwa robotnicze wydzierżawiały za czynsz mieszkania, towarzystwa urzędnicze natomiast miały znacznie większy wkład własny i były zamożniejsze, przykładowy dom w Kolonii z 1914 roku miał mieszkania o wielkości 46-68 m². Inne towarzystwa sprzedawały na własność całe domki ${ }^{33}$. W 1890 roku odbyła się debata berlińskiego Związku Architektów o reformie mieszkań czynszowych (Paul Wolf, Paul Mebes, Erich Köhn, Bruno Taut, Walter i Karl Koeppen). Alfred Messel w 1893 roku z ramienia Berliner Spar- und Bauverein wybudował dwa domy w Moabicie, dwa inne (1897-1899) przy Proskauer Strasse i Weisbachstrasse (1899-1905) $)^{34}$. Na ziemiach polskich w zaborze pruskim rozwój spółdzielczości zaczął się w latach 60., jednak dopiero pod koniec wieku XIX powstały pierwsze spółdzielnie budowlane, stanowiące zaczątek spółdzielni mieszkaniowych. W 1889 roku wydana została ustawa prawa spółkowego tworząca ramy prawne dla spółek z ograniczoną odpowiedzialnością (Erwerbs- und Wirtschaftsgenossenschaften). Pierwsze Towarzystwo Pomoc - Spółka Budowlana, zostało założone 27 marca 1890 w Poznaniu przez dr. Józefa Kusztelana, ówczesnego dyrektora Banku Spółek Zarobkowych i Gospodarczych. Miało ono pomnażać polski stan posiadania w Poznaniu, ale też zajmować się wspieraniem i udzielaniem corocznej subwencji Teatrowi Polskiemu. Do spółdzielni przystąpiło 71 członków z Poznania i 103 z całej Wielkopolski oraz 14 z Galicji i Królestwa. W 1891 roku na przykład spółdzielnia zbudowała w Poznaniu dwa domy przy ulicy 27 Grudnia, ukończone po dwóch latach. Spółdzielnia „Dom Przemysłowy” wybudowała od 1890 roku w ciągu trzech lat dom przy Placu Wolności 18. W Poznaniu istniały też inne spółdzielnie budowlane: Jeżyce - Spółka Budowlana, Letnisko - Poznań, Gromada - Spółka Budowlana. W 1901 roku powstała spółdzielnia budowlana

${ }^{33}$ C. Zimmermann, Wohnen als sozialpolitische Herausforderung..., s. 604-607, 629; H. Matzerath, Urbanisierung in Preußen 1815-1914 ..., s. 298-299.

${ }^{34}$ C. Zimmermann, Wohnen als sozialpolitische Herausforderung..., s. 610-611. 
„Gniazdo” przy towarzystwie gimnastycznym „Sokół”. Pod zaborem pruskim w 1918 roku działało aż 316 spółdzielni różnego typu. Poza Poznaniem także w innych miastach zaboru pruskiego przed 1918 rokiem istniały liczne spółdzielnie mieszkaniowe: w Bydgoszczy, Gnieźnie, Lesznie, Kościanie, Szamotułach, Swarzędzu, Inowrocławiu, Zbąszyniu, Wągrowcu. W sumie w Wielkopolsce - 17 dużych spółdzielni mieszkaniowych z zasobami w 18 miastach. Na ogół budowano tu domy solidne o dobrym standardzie, lepsze niż np. w Galicji ${ }^{35}$. Podobne polskie spółdzielnie mieszkaniowe istniały na Śląsku i Pomorzu Gdańskim - w Tczewie, Chojnicach, Grudziądzu, Świeciu, Toruniu, Starogardzie, Działdowie ${ }^{36}$.

Jakość mieszkań klas niższych była jednak najczęściej bardzo niezadowalająca. Tak było w wypadku milionów robotników rolnych we wschodnich prowincjach Prus, niby wolnych, ale zależnych we wszystkim od swych pracodawców, żyjących w nędznych chatach. Max Weber przeprowadził w latach 1891/1892 ankietę w tym środowisku, której rezultaty były bardzo pesymistyczne. Na Śląsku na robotnika rolnego (Insten, Gärtner) przypadało 3-5 $\mathrm{m}^{2}$ powierzchni mieszkalnej, a domy tych ludzi junkrzy określali jako ,jaskinie zbrodni”. Wbrew potocznym wyobrażeniom warunki życia robotników w wielkim przemysłowym mieście były lepsze niż robotników dniówkowych w teoretycznie ,zdrowych warunkach wiejskich" ${ }^{37}$.

\section{Państwo i władze komunalne wobec budownictwa}

Prawo budowlane do połowy XIX wieku pozwalało na całkowitą anarchię w zabudowie miast i nie dawało szans na sensowny porządek urbanistyczny, a do końca stulecia nabierało dopiero rozpędu. W XVIII wieku istniały zróżnicowane lokalnie ordynacje budowlane i w Landrechcie z 1794 roku pojawiły się pierwsze zapisy, że żadna inwestycja budowlana nie może być podjęta ze szkodą dla dobra publicznego i wbrew interesowi miasta. Były to jednak jedynie dyrektywy, które przecierały ścieżki kodyfikacyjne bez większego praktycznego jeszcze

\footnotetext{
${ }^{35}$ L. Trzeciakowski, Warunki kształtowania się spółdzielczości polskiej w pod zaborem pruskim, w: 90 lat spółdzielczości mieszkaniowej w Polsce (1890-1980), red. J. Topolski, Poznań 1982, s. 9-22; C. Burdziński, Wielkopolska spółdzielczość mieszkaniowa w latach 1890-1945, w: 90 lat spółdzielczości mieszkaniowej..., s. 23-29.

${ }^{36}$ S. Kukuryka, Dorobek polskiej spółdzielczości mieszkaniowej, w: 90 lat spółdzielczości mieszkaniowej..., s. 51.

${ }^{37}$ C. Zimmermann, Wohnen als sozialpolitische Herausforderung..., s. 520-524; B. Fuhrmann, W. Meteling, B. Rajkay, M. Weipert, Geschichte des Wohnens von Mittelalter..., s. 124-126.
} 
zastosowania. W 1855 roku administracja komunalna otrzymała ustawą prawo do ustalania planu zagospodarowania miasta i była to pierwsza pruska norma prawna o większym znaczeniu. Plan zabudowy Berlina Jamesa Hobrechta powstał w 1862 roku (1858?). Podobnie jak w zakresie innych instytucji i urządzeń socjalnych, Rzesza i Prusy szybko wdrażały nowe rozwiązania w dziedzinie prawa budowlanego. W innych zaborach działo się to do wybuchu pierwszej wojny światowej, przy czym w zaborze rosyjskim były to rozwiązania bardzo niedoskonałe. Sprawę organizacji miejskiej posunęła w Prusach ustawa z 1875 roku, mająca bardziej praktyczne znaczenie niż rozwiązania z roku 1855. Dawała władzom komunalnym uprawnienia do regulowania przebiegu linii komunikacyjnych, ulic i położenia domów (Bauflucht). Około roku 1900 narastała ilość prawnych i policyjnych regulacji budowlanych oraz nadzoru administracyjno-policyjnego. Nie można też zapomnieć o lokalnych rozwiązaniach budowlanych, jak ordynacja budowlana dla Berlina z 1853 roku, która dla prowincji wschodnich Prus miała charakter wzorcowy.

Mimo regulacji rosnące osiedla robotnicze (Mietskaserne) pęczniały chaotycznie i bez planu, co stawało się zagrożeniem sanitarnym, przestępczym i komunikacyjnym. Urzędnicy komunalni w miastach pruskich zdawali sobie też sprawę z konieczności regulowania kwartałów mieszkalnych, rzemieślniczych i fabrycznych, które emitowały sadzę, hałasowały nie do zniesienia, zadymiały i roztaczały fetor. Poszczególne miasta, jak Kolonia, czy Frankfurt nad Menem wydawały w tej sprawie własne ordynacje budowlane, umożliwiające zaprowadzenie porządku w miastach. Wyrok naczelnego sądu administracyjnego z 1882 roku takich lokalnych regulacji jednak zasadniczo zakazywał. Okazało się, że w pewnych kwestiach związanych z regulacjami prawnymi budownictwa Prusy odstają wobec innych landów, bo Bawaria wprowadziła planowanie miasta według rodzajów zabudowy w 1904 roku, a Saksonia w roku $1900^{38}$. Niemniej sytuacja ulegała wielkim zmianom.

Narastanie napięć związanych z mieszkalnictwem, wynikających również z ograniczonych możliwości technologicznych wieku XIX, powodowało wzrost zainteresowania tą kwestią władz komunalnych. We władzach miast właściciele i możni byli nadreprezentowani i jeszcze w latach 60. nie śpieszono się z planami

${ }^{38}$ J. Reulecke, Die Mobilisierung..., s. 62-64; C. Zimmermann, Wohnen als sozialpolitische Herausforderung..., s. 614-615; J. Kuczynski, Geschichte des Alltags..., s. 208; H. Matzerath, Urbanisierung in Preußen 1815-1914..., s. 290-293; J. Pazdur, Budownictwo, w: Historia kultury materialnej Polski..., s. 291-292. 
zabudowy, które oznaczały uszczuplenie praw właścicieli i nierzadko kosztowne dla miasta inwestycje budowlane. Coraz trudniejsze fachowe problemy wielkich aglomeracji zaczęli stopniowo też rozwiązywać już nie zamożni deputowani, ale fachowcy: urzędnicy administracji, architekci, inżynierowie i inni przedstawiciele inteligencji technicznej, księgowi i finansiści, urbaniści oraz lekarze. Szybko stworzyli oni nową grupę o silnym poczuciu odrębności, stylizując się na rzekomo ponadpartyjnych „technokratów”, reprezentantów „dobra wspólnego”. Była to warstwa pozytywistyczna i nastawiona choćby z konieczności na realizację interesów nie tylko elit, ale i całej wspólnoty. Posługiwała się narracją walki z zacofaniem i anachronizmami, burzenia niezdrowych, cuchnących, ciasnych średniowiecznych uliczek i zastępowania ich nowoczesnymi, przestronnymi traktami ze świeżym powietrzem, parkami, klombami z zielenią, wygodnymi do komunikacji i oddychania. Krytycy nazywali ten styl ironicznie ,socjalizmem municypalnym” czy też „Gas-Wasser-Sozializmus”. Pojawiły się nowe formy organizacji miejskiej walki z ubóstwem - między innymi wprowadzenie gazownictwa, które pojawiło się w tym czasie i zaczęło się od gazowego oświetlenia ulic, a następnie przyszedł czas na kuchenki gazowe i gazowe ogrzewanie ${ }^{39}$.

To wszystko teoretycznie brzmi dobrze, jednak panujący do ostatnich dziesięcioleci XIX wieku wrogi wszelkim ingerencjom państwa porządek liberalny, a tych ingerencji nie było przecież wówczas wiele, połączony był z anarchicznym i rakowatym wręcz rozrostem niezdrowej tkanki miejskiej. Stanowił też krok wstecz wobec ordynacji budowlanych w XVIII wieku, zaś otrzeźwienie przychodziło stopniowo. W wieku XIX rozrost miast powiązany był ze spekulacjami ziemią i miał charakter bardzo chaotyczny, ponieważ na pierwszym planie stała bezwzględna walka o zysk. $Z$ jednej strony bardzo wysokie były ceny na grunty pod „koszary czynszowe”, np. w Berlinie w latach 1912-1914. Na cenę miało wpływ oddalenie od centrum, sytuacja komunikacyjna, społeczna i topograficzna. Powstała też swego rodzaju spekulacyjna pętla. Ceny gruntów w konkretnych miejscach władze podnosiły już z założeniem dalszego ich wzrostu po rozpoczęciu ruchu budowlanego. Następnie, dla obniżenia kosztów i przyśpieszenia zysków, budowy prowadzono w pośpiechu, zaciągano nadmierne w stosunku do możliwości przedsiębiorstwa kredyty, co potem zmuszało też do podnoszenia czynszów i budowania coraz wyższych kamienic. Oczywiście występowały też

\footnotetext{
${ }^{39}$ A. von Saldern, Im Hause, zu Hause..., s. 182-183; W. Benjamin, Berlińskie dzieciństwo..., s. 13.
} 
pewne zwykłe falowania koniunktur na rynku budowlanym - wzrost grynderski do 1875 roku, potem spadek cen do roku 1883 i ponowny wzrost cen, i to wyższy niż innych towarów konsumpcyjnych. Wreszcie były też różnice lokalne - jedne miasta były znacznie droższe od innych. Najdroższy był Berlin, gdzie wynajęcie dwupokojowego mieszkania w 1885 roku kosztowało przeciętnie 336 marek, w 1905 roku 418 marek, a pięciopokojowe - odpowiednio 1255 marek i 1355 marek. Czynsz w przeciętnym mieszkaniu w Berlinie wynosił w 1910 roku 720 marek, a w Barmen 250. Na wschodzie dochody były jednak niższe i przez to ceny wydawały się relatywnie wyższe. Przy tym za mieszkania najmniejsze, a więc najchętniej wynajmowane przez robotników, trzeba było zapłacić najwięcej. W rezultacie robotnik przy dochodzie 1200 marek na wynajęcie mieszkania wydać musiał $20 \%$, a przy mniejszych nawet $25 \%$ pensji, gdy zamożne mieszczaństwo $10 \%{ }^{40}$.

W obliczu narastających napięć społecznych elity konserwatywne zaczęły skłaniać się do poglądu o konieczności ustępstw wobec robotników, aby rozładować frustracje w tej klasie społecznej i nie doprowadzić do wybuchów społecznej przemocy. Konserwatysta Adolf Wagner ${ }^{41}$ pisał o konieczności zaprowadzenia ładu w stosunkach między przedsiębiorcami i robotnikami. Mieli oni zostać „usynowieni” w paternalistycznej relacji znanej ze świata szlacheckiego, gdzie junkier miał być ojcem, surowym i wymagającym, ale też kochającym i opiekuńczym wobec poddanych. Robotnikom obiecano poprawę położenia materialnego i opiekę instytucjonalną państwa. Wagner uznał socjalne postulaty redystrybucyjnego charakteru podatków, które miały nieco zmniejszyć dysproporcje płacowe poprzez wyrównywanie ich przez państwo. Wprowadzić miano ubezpieczenia chorobowe, emerytury, zakaz pracy dzieci i kobiet, zakaz pracy w niedziele, ale jeszcze nie ubezpieczenia od bezrobocia (dopiero w Republice Weimarskiej). Problem mieszkaniowy (Wohnungsfrage) uznał Wagner za jedną z centralnych kwestii, które rozwiązać musi państwo. A właściwie nie tyle rozwiązać, co złagodzić problemy, ponieważ Wagner sądził, że natura świata jest grzeszna i przezwyciężyć się jej nie da, chociaż można ją znacznie poprawićt ${ }^{42}$. Niemiecka, a w szczególności pruska myśl i ekonomia, już od kameralizmu,

\footnotetext{
${ }^{40}$ J. Kuczynski, Geschichte des Alltags..., s. 206; T. Nipperdey, Deutsche Geschichte $1866-$ 1918..., s. 136-137, 144-145; H. Matzerath, Urbanisierung in Preußen 1815-1914..., s. 287.

${ }^{41}$ R. Craemer, Der Kampf um die Volksordnung. Von den preußischen Volkspolitik, Hamburg 1933, s. 112-113.

${ }^{42}$ Tamże, s. 114.
} 
będącego początkiem etatyzmu i interwencjonizmu, rozwijała się inaczej i niezależnie wobec doktryn angielskich i francuskich. Tutaj zupełnie naturalnie zdecydowanie większą rolę przywiązywano do znaczenia państwa i prawa (Savigny, Ranke), jako że tylko państwo w zacofanej i agrarnej Europie Wschodniej mogło dać impuls do rozwoju cywilizacyjnego. Prawdę mówiąc, ten kierunek narastał już od czasów Fryderyka Wilhelma I, o ile nie Wielkiego Elektora ${ }^{43}$. Było to myślenie Gustawa Schmollera, któremu z kolei przeciwstawiał się liberał Treitschke, akcentujący odpowiedzialność jednostki za siebie i wyszydzający płaskość apolitycznego optymizmu. Liczyła się dla niego jednak nie jednostka, ale wspólnota, widziana wszakże przez pryzmat interesów elit, które (za Heglem) stały na pierwszym miejscu. Akceptował jedynie filantropię, a działania socjalne państwa odrzucał, jak wszyscy ówcześni liberałowie, istniejące wielkie nierówności klasowe uważał za nieuniknione i naturalne, a masową nędzę uznawał za nieuchronną konsekwencję postępu. Za fundament porządku uznawał święte prawo własności prywatnej, a próby zrównywania majątkowego - za niegodziwe ${ }^{44}$.

Polskie elity nieufnie odnosiły się do ingerencji pruskiej władzy, czujnie tropiąc przejawy kolonializmu i germanizacji, czemu trudno się dziwić, ponieważ było ich pod dostatkiem i nieufność była uzasadniona. Jak zwraca uwagę Szczepan Wierzchosławski, praworządność i wysoki poziom administracji pruskiej i jej reform, widoczny dobrze na tle korupcji i nieudolności w zaborze rosyjskim, był pod zaborem pruskim doceniany, ale nie powodował entuzjazmu do Prusaków ${ }^{45}$.

Ważną rolę w intelektualnym przepracowaniu kwestii mieszkaniowej odegrał Aime Huber oraz powstałe w 1844 roku berlińskie towarzystwo Centralverein für das Wohl der arbeitenden Klassen. Kwestią mieszkaniową interesowali się nie tylko politycy i ideologowie. Sprawa mieszkaniowa stała się przedmiotem publicznej debaty. Przyczyniał się do tego również rozwój statystyki, który ukazywał szerszy wymiar problemu. Narastało zaniepokojenie zagrożeniami niedoboru i niskiej jakości mieszkań w wielkich miastach, nazywane „głodem mieszkaniowym”. Przy tym próby rozwijania spółdzielczości albo rozwiązania problemu przez mieszkania własnościowe nie przynosiły zadowalających efektów i stanowiły jedynie uzupełnienie rynku mieszkań na wynajem. Bez wątpienia napięcia

43 Tamże, s. 115.

${ }^{44}$ Tamże, s. 116-117.

${ }^{45} \mathrm{~S}$. Wierzchosławski, Orzet czarny i orzet biały. Problemy modernizacji społeczeństwa polskiego prowincji Prusy Zachodnie w XIX i na początku XX w., Olsztyn 2011, s. 11-12. 
narastały także z powodu całkowitego urynkowienia mieszkań, traktowanych jak każdy inny towar. Od lat 70. lekarze zwracali uwagę na tzw. higienę społeczną (Sozialhygiene) - przerażenie budziły nieczystości, „miazmaty”, rzeźnie, brak albo zbyt powolny rozwój kanalizacji i wodociągów. „Hygienicy” społeczni zajmowali się też kwestiami jakości żywienia, klimatu, wody i ziemi, szkodami dla zdrowia robotnika, wynikającymi z nieodpowiednich form pracy. Gruźlicę kojarzyli właśnie z nieodpowiednimi warunkami mieszkaniowymi. Oceniali minimalną wielkość mieszkania i racji żywnościowych potrzebnych człowiekowi do normalnego funkcjonowania. Był to też początek refleksji nad pensjami minimalnymi i ich związkiem z kosztami utrzymania.

Podjęto kwestię kontroli jakości wykonania domów i materiałów budowlanych w budownictwie. W latach 80 . XIX wieku za niezbędną do mieszkania i życia przestrzeń uznawano dziesięć kubikometrów; w 1900 - dwadzieścia kubikometrów. Coraz bardziej podkreślano konieczność wyposażenia każdego mieszkania, a nie tylko mieszkań ludzi zamożnych, w toaletę, kanalizację i wodociąg. Wszystko to działo się jeszcze przed odkryciem bakterii. Do końca lat 70 . wypracowana została koncepcja zdrowotnej kontroli problematyki mieszkaniowej, kontroli norm budowlanych, co było później wdrażane jako nadzór państwa nad budownictwem. W sferze publicznej działał „Verein für Öffentliche Gesundheitspflege” (1873), wzorujący się na angielskim ruchu „Public Health”46.

Ruchy społeczne były jednak zniechęcone, bo jedynym skutkiem ich działań było wyrzucanie na bruk biednych ludzi mieszkających w nędznych norach, niespełniających żadnych standardów. Ofiarami stawali się ci, których los chciano poprawić. Zaczęto się wobec tego koncentrować na podnoszeniu jakości nowobudowanych mieszkań i planowaniu zdrowej struktury zabudowy miejskiej. Koszary czynszowe (Mietskaserne) wydawały się już zupełnie nie do przyjęcia. Rozważano więc budowę mniejszych domów na 6, 4, czy 2 rodziny ${ }^{47}$. Lokalna policja, a potem władze miejskie, zaczęły sprawdzać, czy mieszkania posiadają niezbędne minimum higieniczne i metrażowe. Najczęstszymi problemami były cieknące dachy, za małe okna, brudne toalety, brak odpowiednich warunków przeciwpożarowych. W Prusach jednak, inaczej niż w innych państwach niemieckich, nie wprowadzono żadnych prawnych rozwiązań w zakresie kontroli warunków minimalnych. Dominowały poglądy raczej liberalne. W 1872 roku

\footnotetext{
${ }^{46}$ C. Zimmermann, Wohnen als sozialpolitische Herausforderung..., s. 531-534.

${ }^{47}$ Tamże, s. 535.
} 
minister Heinrich von Itzenplitz pisał do Bismarcka, że zdaje sobie sprawę, że na rynku mieszkaniowym są ogromne braki, ale każda ingerencja w rynek pogorszy jedynie sytuację. Dopuszczał jedynie myśl o budowie mieszkań dla urzędników i pracowników państwowych. Tradycyjnie państwo troszczyło się też o mieszkania dla górników i oficerów ${ }^{48}$.

W Berlińskim Związku Architektów w latach 1890 i 1891 rozważano projekty minimum mieszkaniowego w czynszówkach dla robotników. Osobne mieszkanie dla każdej rodziny robotniczej wydawało się projektem nierealistycznym, ale prace zmierzały w stronę takich właśnie, obliczonych na dalszą perspektywę, rozwiązań, koncentrując się na małych, ale funkcjonalnych mieszkaniach wyposażonych już w nowoczesne rozwiązania techniczne i sanitarne. Zwracano uwagę, że w ówczesnej Anglii nawet najmniejsze domki robotnicze takie udogodnienia już posiadały ${ }^{49}$. Od schyłku XIX wieku narastała świadomość potrzeby wkroczenia polityki socjalnej w sferę mieszkalnictwa, aczkolwiek cały czas sprzeczano się, czy ideałem będą małe domki przyzakładowe na przedmieściu, czy mieszkania w kamienicach czynszowych ${ }^{50}$.

Lewe skrzydło SPD początkowo interpretowało katastrofalną sytuację mieszkaniową jako korzystny stan prowadzący do oczekiwanej rewolucji, potem jednak postawiono na pragmatyczne wspieranie konkretnych działań pozytywnych w miastach i gospodarce komunalnej. SPD wspierała budowę przez gminy małych mieszkań na wynajem dla mniej zamożnej ludności. Od czasów reform Steina 1/2 deputowanych miejskich stanowili jednak zamożni właściciele domów, niezbyt chętni do wspierania słabszych, co sam Stein po czasie ocenił jako zbyt daleko posuniętą dominację możnych, zaburzającą równowagę społeczną. Jak stwierdził, w znacznie większym stopniu powinny być reprezentowane również „wykształcenie” i „talent”, które nie wiązały się z pieniędzmis ${ }^{51}$. Po 1871 roku trzyklasowe cenzusowe prawo wyborcze w miastach nadal faworyzowało najzamożniejszych i wpływało na bardzo konserwatywną politykę mieszkaniową ${ }^{52}$.

Poza mieszkaniami dla urzędników miejskich, komunalnych inicjatyw budowlanych było więc niewiele: w Düsseldorfie 420 mieszkań w latach 1900-1913,

\footnotetext{
${ }^{48}$ Tamże, s. 625-628.

49 Tamże, s. 544-547; T. Nipperdey, Deutsche Geschichte 1866-1918..., s. 137.

${ }^{50}$ C. Zimmermann, Wohnen als sozialpolitische Herausforderung..., s. 554-555.

${ }^{51}$ J. Reulecke, Die Mobilisierung..., s. 29-30.

52 Tamże, s. 32.
} 
w Ulm domki jedno- i dwurodzinne dla 2700 mieszkańców, 32 tys. talarów wydano na mieszkania robotnicze w Halle nad Soławą. Były to pojedyncze odosobnione projekty, które jednak zapowiadały przyszłe zmiany. Bardzo długo istniała fiksacja władz na budownictwo indywidualne, jedno- i dwurodzinne, mimo że było ono nieekonomiczne, niepraktyczne i drogie. W 1907 roku weszła ustawa mająca chronić interesy najemców, ale jej działanie było minimalne. Napięcia społeczne na tle mieszkaniowym były bardzo znaczne, w Berlinie dochodziło do zamieszek i walk ulicznych z robotnikami. Oburzenie wywoływały przede wszystkim spekulacje ziemią i oszustwa oraz traktowanie mieszkania jako zwykłego źródła kapitalistycznego dochodu ${ }^{53}$.

W całej Europie próbowano zaradzić sytuacji, ale reformy i wznoszone robotnicze kamienice i domy przed 1918 rokiem miały incydentalny charakter. Imponujący projekt domu francuskiego z 1200 drzwiami i oknami o długości 180 metrów z końca XIX wieku krytykowany był za niedostatki urządzeń sanitarnych i wodno-kanalizacyjnych. Powstała robotnicza ulica w Marsylii, mówiło się o zapędzeniu państwa do finansowania budownictwa robotniczego, ale liberałowie opierali się twierdząc, że nic nie da się zrobić. We Francji pojawiły się też propozycje podatku na rzeczy higieny publicznej dla sfinansowania robotniczych mieszkań (1899) i nieliczne jeszcze mieszkania finansowane przez państwo $^{54}$. Głos typowego francuskiego liberała ociekał jednak pogardą: „Wszystko, co społeczeństwo może zrobić, w swoim własnym interesie, to prowadzić surowy nadzór nad ich norami, oczyszczać je, dezynfekować, gdy dany przypadek tego wymaga, nie pytając o zdanie (tych rodzin), podobnie jak oczyszcza się ścieki nie przejmując się szczurami, które obrały je sobie za mieszkanie" ${ }^{55}$.

\section{Przyklady rozwoju urbanistycznego}

Oczywiście najszybciej rozwijało się w Prusach budownictwo mieszkaniowe Berlina, ale jednocześnie tu też, przy zbyt szybkim wzroście liczby mieszkańców, największe były mieszkaniowe problemy, kontrasty i niedomagania. Wcale nie lepsze były jednak oceny Paryża tego czasu, gdzie mówi się o skandalicznych

\footnotetext{
${ }^{53}$ Tamże, s. 557-559; P.H. Feist, Geschichte der deutschen Kunst..., s. 268-269.

${ }^{54}$ G. Vigarello, Historia zdrowia i choroby..., s. 242-243.

${ }^{55}$ Tamże, s. 243.
} 
warunkach życia ludu, co sprowadzało się do zarzutu ciasnoty i marnych warunków higienicznych ${ }^{56}$.

Wielkość mieszkań w Berlinie w 1875 roku (osoby)

\begin{tabular}{|l|c|c|c|c|c|c|c|}
\cline { 2 - 8 } \multicolumn{1}{c|}{} & Samotni & Małżeństwo & Dziecko & Krewni & Służba & Inni & Suma \\
\hline Bez ogrzewania & 178 & 314 & 302 & 27 & 112 & 67 & 9885 \\
\hline 1 ogrzewany pokój & 85 & 392 & 359 & 34 & 19 & 111 & 253510 \\
\hline 1 ogrz. i nieogrz. & 48 & 345 & 367 & 38 & 36 & 166 & 172114 \\
\hline 2 ogrzewane & 48 & 336 & 353 & 46 & 64 & 154 & 249849 \\
\hline 3 ogrzewane & 58 & 295 & 329 & 58 & 141 & 118 & 107326 \\
\hline 4 ogrzewane & 51 & 270 & 324 & 53 & 210 & 92 & 53051 \\
\hline 5 ogrzewanych & 47 & 262 & 313 & 54 & 246 & 79 & 33743 \\
\hline 6 ogrzewanych & 43 & 241 & 318 & 51 & 283 & 64 & 21558 \\
\hline 7 i więcej ogrz. & 30 & 202 & 291 & 39 & 357 & 81 & 39565 \\
\hline
\end{tabular}

Źródło: W.H. Hubbard, Familiengeschichte. Materialien zu deutschen Familie seit dem Ende des 18. Jahrhunderts, München 1983, s. 145.

Między rokiem 1870 a 1900 zagęszczenie działki budowlanej w Berlinie wzrosło z 58 do 77 osób, ale do 1910 roku spadło do 76, w 1917 - do 63. Po 1875 roku szybko za to zaczęły rosnąć różnice zagęszczenia ludności w poszczególnych dzielnicach, co oznacza różnicowanie się społeczne dzielnic, podział na city, mieszkalne i przemysłowe, gorsze i lepsze adresy, droższe i tańsze kwartały i ulice. W city znajdowały się sklepy i domy towarowe, banki, towarzystwa ubezpieczeniowe, redakcje gazet, wydawnictwa, hotele, restauracje, teatry, muzea, siedziby administracji i urzędów, władz państwowych i kościelnych, siedziby władz wielkich firm, organizacji i związków oraz towarzystw. Zwykle w tej okolicy znajdował się też główny dworzec kolejowy.

Dzielnice mieszkalne, z powodu wyższych czynszów, wypychane były z centrum na obrzeża. Różnice były też wewnętrzne. Nie chodzi tylko o większą liczbę osób przypadających na izbę, ale o niższe domy, większą liczbę willi, ogrodów, parków i terenów zielonych w zamożniejszych dzielnicach. Różnice wahały się między 20 a 100 osobami na działkę $e^{57}$. W dzielnicach robotniczych narastała zabudowa coraz wyższych koszarowych czynszówek na wąskich parcelach.

${ }^{56}$ M. Perrot, Sposoby zamieszkiwania, w: tejże, Historia życia prywatnego, t. 4, Wrocław 1999, s. $366-367$.

${ }^{57}$ M. Erbe, Berlin im Kaiserreich (1871-1918), w: Geschichte Berlins, Bd. 2, hrsg. v. W. Ribbe, Berlin 2002, s. 700; H. Matzerath, Urbanisierung in Preußen 1815-1914 ..., s. 284-286. 
W 1910 roku w samym Berlinie było 20 tys. mieszkań piwnicznych, w których mieszkało około 60 tys. ludzi. Poza tym większość mieszkań miała bardzo małą powierzchnię i składała się z jednej izby i kuchni bez toalety. W dzielnicy Wedding udział mieszkań jednoizbowych w 1905 roku wynosił 55\%, w Gesundbrunnen $60 \%$. Jeszcze w 1918 roku 40\% mieszkań w Berlinie miało tylko jedną izbę. Ceny berlińskie przez cały XIX wiek rosły, ale po 1890 roku stopniowo ulegały stabilizacji. W 1907 roku najemcy, którzy zarabiali do 3000 marek (32\% ludności), wydawali na czynsz $18 \%$ pensji. $79 \%$ z tego zarabiało zaledwie do 1200 marek rocznie. Najtańsze mieszkania przy takich zarobkach stanowiły 1/3-1/4 miesięcznej pensji. Kanalizacja i wodociąg stały się powszechne w początku lat $90 .{ }^{58}$

W odniesieniu do budownictwa Berlina wypowiadała się krytycznie z pozycji liberalnych hrabina Dohna. Atakowała fatalne warunki zdrowotne i sanitarne życia zwykłych ludzi w Berlinie i postulowała założenie pasa zieleni jako Ringu, tworzenie ogródków jordanowskich dla dzieci, i parków, przedszkoli oraz szpitali. Takie ogrody i parki stawały się nie tylko w Berlinie, ale i w innych miastach, jak Kolonia, coraz modniejsze, stając się do dzisiaj trwałą tradycją życia miejskiego ${ }^{59}$.

Szczecin do połowy XIX wieku rozwijał się bardzo rachitycznie. Na początku wieku liczył 18 tys. mieszkańców ${ }^{60}$. Po 1871 roku zabudowa miejska, zwłaszcza po likwidacji twierdzy, szybko rozprzestrzeniała się geometrycznie i wedle struktury gwiaździstej, nie licząc się specjalnie z potrzebami mieszkańców. Tylko w latach 1872-1875 wybudowano 500 nowych domów, a później ruch budowlany wcale nie osłabł. Budowano jednak długo bez urbanistycznego planu, parcelowano kolejne geometryczne kawałki miasta pod zabudowę mieszkalną. Decydował przede wszystkim liczbowy wzrost rodzin robotniczych i idący za tym wzrost cen działek i wysokości czynszów. Zalecenia policji budowlanej i regulacja z 1874 roku wyznaczały szerokość ulic i chodników. Podobnie jak w całych Prusach, nadmiernie rosła gęstość zaludnienia, ciasnota i czynszówki (Mietskaserne), czyli koszary czynszowe. Brakowało placów do zabaw i gier dla dzieci, parków, miejsc do uprawiania sportu. Największe skupiska ludności

\footnotetext{
${ }^{58}$ M. Erbe, Berlin im Kaiserreich..., s. 702-704.

${ }^{59}$ P.H. Feist, Geschichte der deutschen Kunst..., s. 266-267.

${ }^{60}$ L. Turek-Kwiatkowska, Życie codzienne..., s. 13.
} 
robotniczej znajdowały się w Szczecinie na obrzeżach miasta, co do pewnego stopnia neutralizowało konflikty społeczne i polityczne ${ }^{61}$.

Były też jednak solidne kamienice mieszczańskie, czterokondygnacyjne. $\mathrm{Na}$ początku XX wieku bogaci przenosili się do okazałych willi na obrzeżach miasta na osiedlu Neu Westend. Potem, nieopodal dworca niebuszewskiego, powstało osiedle na 1100 mieszkań. Na Pomorzanach i Drzetowie budowano 560 niewielkich mieszkań - pokój z kuchnią, 34 metry. Dopiero po roku 1905 spadła znacznie liczba zezwoleń na budowę i ruch budowlany osłabł. Wyburzano jednak budynki niespełniające już wymogów technicznych ${ }^{62}$.

Uwarunkowania i ograniczenia rozwoju przestrzennego miast miały zróżnicowany charakter. W Poznaniu granice rozwoju wyznaczały fortyfikacje miejskie, które ograniczyły jego wewnętrzny obszar do 950 ha. Ustalona wielkość posesji wynosiła tu od 15,7 do 31,5 metra szerokości oraz 40-60 metrów głębokości, co determinowało wydłużony kształt kamienic. Podobnie to wyglądało w innych miastach, także w Berlinie. Do 1877 roku obowiązywała ordynacja budowlana dająca całkowitą swobodę w kształtowaniu wysokości i fasad domów, „byle nie obrażały oka". Po 1871 roku panował zwiększony ruch budowlany, a domy ze względu na rosnącą cenę gruntu były coraz wyższe. Gorączka budowlana prowadziła do spekulacji i oszustw. Miejsce przygotowane na park miejski (między ulicą Berlińską a św. Marcinem) zostało zabudowane ciasno przez budynki o charakterze komercyjnym.

Tylko w latach 1871-1872 wydano w Poznaniu aż 408 pozwoleń na budowę (w tym samym czasie np. w Krakowie - 46). Najpowszechniejszą formą budownictwa mieszkalnego była kamienica czynszowa. Ze względu na brak wielkiego przemysłu i dominację drobnych przedsiębiorstw i warsztatów rzemieślniczych, nie było pałaców fabrykantów i dzielnic czynszowych koszar robotniczych. W kamienicy od frontu mieszkali bogaci kupcy, rentierzy, przedsiębiorcy, zamożniejsza inteligencja; w bocznych i tylnych oficynach warstwy uboższe. Dla proletariatu przeznaczone były sutereny i strychy oraz stare domy we wschodniej części miasta.

O charakterze miasta świadczyły oczywiście mniej lub bardziej okazałe gmachy publiczne w centrum, których liczba w XIX wieku bardzo wzrosła

${ }^{61}$ E. Włodarczyk, Rozwój przestrzenny i demograficzny miasta..., s. 290-294, 312-313; L. Turek-Kwiatkowska, Życie codzienne..., s. 15.

${ }^{62}$ L. Turek-Kwiatkowska, Życie codzienne..., s. 15-16. 
wraz z rozrostem instytucjonalnym państwa ${ }^{63}$. Do takich należały: Biblioteka Raczyńskich, Ziemstwo Kredytowe i Bazar, Teatr Polski, gmach Poznańskiego Towarzystwa Przyjaciół Nauk, budynki Prezydium Policji, Gimnazjum Fryderyka Wilhelma, Rejencja, nowe sądy, poczta i in. W 1877 roku wprowadzono nową ordynację budowlaną, na skutek której podwórka stały się jeszcze mniejsze i przy domach wyższych przypominały ponure studnie pozbawione światła. Bogaci stali się jeszcze bogatsi, a biedni biedniejsi. Podobnie jak w innych miastach, i tutaj z końcem wieku narastał wspominany ostentacyjny przepych i pompatyczna eklektyczność fasad mieszczańskich kamienic. Szczególnie zwracały dwie nowe ulice wybudowane przez Posener-Bau-Bank z projektami architekta Franka Negendanka - Kantaka i Taczaka (Bismarcka i Ludwiki). Przy pierwszej znajdowały się domy w pałacowym stylu z apartamentami, monumentalnymi klatkami schodowymi oraz kamienice czynszowe w architekturze mieszczańskiej. Prawdziwie magnackie pałace i domy willowe, ze względu na braki przestrzeni, w Poznaniu nie powstawały ${ }^{64}$.

Szybki wzrost ludności i zagęszczenia następował w Królewcu. Jeszcze w 1864 roku mieszkało tam 172 ludzi na hektar, w 1890 roku - 282, w 1895 304, a w 1905 - 364, przy czym w niektórych rejonach zagęszczenie wynosiło nawet 500 osób na hektar. Oznaczało to coraz wyższą zabudowę i ciasnotę w domostwach robotniczych. Miasto samo mieszkań komunalnych nie budowało, ale wspierało towarzystwa budowlane. W Królewcu istniało np. Wohnungsbau Verein; w 1904 roku miasto założyło Stiftung für gemeinnützigen Wohnungsbau ${ }^{65}$.

W małych miastach ruch budowlany był zdecydowanie słabszy, jednak również bardzo widoczny; wzrost gospodarczy nie koncentrował się jedynie w ośrodkach większych. W Bytowie na Pomorzu Zachodnim w roku 1864 było 268 domów, w 1885 - 291, 1900 - 334, 1915 - 512. Podobnie znacznie wzrosła liczba osób zamieszkujących jedno domostwo, a więc domy stawały się większe. W 1819 roku wynosiła ona 8,8 osoby, w 1890 - 16, a w 1910 - 19 osób. Jak stwierdza Józef Lindmayer, ruch budowlany był w Bytowie większy niż w sąsiednim Sławnie czy Darłowie. Tylko w latach 1910-1915 zbudowano tu aż 100 domów mieszkalnych. Przy rynku i głównych ulicach stawiano kamienice zwykle 2-piętrowe,

${ }^{63}$ Z. Ostrowska-Kłębowska, J. Skuratowicz, Architektura i budownictwo, w: Dzieje Poznania, t. 2: 1793-1918, red. J. Topolski, L. Trzeciakowski, Warszawa-Poznań 1994, s. 498-500.

${ }^{64}$ Tamże, s. 504-507.

${ }^{65}$ F. Gause, Die Geschichte der Stadt Königsberg, Köln-Graz 1968, s. 640. 
gdy w wielkich miastach 4-5-piętrowe. Powstawały też domy willowe - pierwsze takie osiedle powstało w 1913 roku. W latach 1910-1911 wybudowano dom komunalny dla urzędników landratury. Postępowały też zmiany cywilizacyjne. W początkach XX wieku uruchomiono agregat prądotwórczy, w 1905 roku instalację elektryczną doprowadzono do magistratu i archiwum miejskiego. W 1910 roku Bytów obsługiwała już regularna elektrownia w Słupsku, która dostarczała prąd dla kilku powiatów ${ }^{66}$.

Spośród innych mniejszych miast pruskich wspomnieć można o Lęborku. Wprawdzie w XIX wieku charakter zabudowy ulegał zmianie i coraz mniej stawiano domów drewnianych, wciąż jeszcze jako źródła światła używano tu otwartych źródeł ognia. Elektryczność, jak wiemy, pojawiła się dopiero pod koniec stulecia. W rezultacie w tym okresie nadal częste były rozległe pożary, niszczące całe kompleksy budynków: w 1859, 1893, 1895, 1899, 1900, 1901, 1903, 1906. I tutaj, jak w Bytowie w XIX wieku, znacznie wzrosło zagęszczenie mieszkańców. Między 1870 a 1880 rokiem nastąpił wzrost liczby budynków w mieście o 23\%. W 1871 roku liczba budynków mieszkalnych wynosiła 389, a w 1905 660. Warto odnotować budowę osiedla dla 50 rodzin robotników fabryki zapałek między 1890 a 1910 rokiem oraz komunalnych domów dla urzędników miejskich wybudowanych w latach 1900-1910. Mimo to rosła liczba mieszkańców przypadających na dom z 8 w 1821 roku na 16 w roku 1880 i 19 w roku 1905. Badacz urbanizacji tego miasta wskazuje na charakterystyczne dla całych Prus nienadążanie rozwoju budownictwa mieszkaniowego za przyrostem ludności ${ }^{67}$.

\section{Dom a rodzina i romantyczne, konserwatywne i lewicowe krytyki upadku cywilizacji}

Podkreślana często waga mieszkania związana była ze wzrostem znaczenia życia rodzinnego. Oczywiście wszystkie jego formy kulturowo związane były ściśle z chrześcijaństwem i jego archetypami, symbolami i metaforami. Przekaz religijny w sferze norm i wartości był najbardziej trwałą formą socjalizacji umocnioną przez emocjonalne przeżycia okresu dzieciństwa. Żadne inne, bardziej rozbudowane konkurencyjne przekazy do ludu nie docierały. W rezultacie w życiu

${ }^{66} \mathrm{~J}$. Lindmayer, Bytów w okresie przemian ustrojowo-prawnych i społeczno-gospodarczych Prus (1815-1918), w: Historia Bytowa, red. Z. Szultka, Bytów 1998, s. 234-237.

${ }^{67}$ M. Stażewski, Dzieje Lęborka 1815-1918, w: Dzieje Lęborka, red. J. Borzyszkowski, Lębork-Gdańsk 2009, s. 306-310. 
rodziny ważne były wzory rodziny Jezusa, a pozycja kobiety u katolików dowartościowana przez wzory maryjne i święte. Trzymano się jednocześnie tradycyjnego podziału ról: kobiety - matki i żony i mężczyzny - głowy rodziny, męża i ojca. Od romantyzmu postępował jednak proces tzw. intymizacji, a więc wzrastało znaczenie uczuciowości, czułości i ciepła w relacjach rodzinnych, a dziecko zaczynało mieć $\mathrm{w}$ rodzinie znacznie wyższą pozycję. Ten proces znajdował swoje przedłużenie w konstruowaniu przestrzeni mieszkalnej, gdzie najpierw wyodrębniono pokój dziecięcy, kobieta otrzymała buduar, wzrosła rola wspólnych rodzinnych posiłków i innych form wspólnego spędzania czasu. Wraz z tym rosła rola mieszkania, które nie było już tylko schronieniem przed zimnem i sypialnią, ale też miejscem rozwijania i spajania więzi rodzinnych.

Taki obraz życia dotyczył jednak zamożnego mieszczaństwa, obraz, który stał się wzorem dla wyobrażeń ludzi XX wieku. Z drugiej strony przez kraj przetaczała się wielka fala krytyki życia wielkomiejskiego. Miała ona bardzo stare korzenie, widoczne najpierw w antyku, kiedy to chętnie wyjeżdżano do wiejskich villi, traktując je jako oazy spokoju, a miasto uważano za niemoralne; następnie w szlacheckiej pogardzie dla mieszczaństwa i przekonaniu o mieście jako siedlisku rozpusty, przestępczości i wszelkiego zła. Oświeceniowy spór „swojskości” $\mathrm{z}$ „cudzoziemszczyzną” również miał w tle konflikt wsi z miastem. Jerzy Jedlicki wskazuje, że dostrzegano w XIX wieku dualizm - miasto niesie szybki postęp techniczny i ekonomiczny, ale też zepsucie i demoralizację. Tę dychotomię zauważa też Przemysław Matusik w katolickim piśmiennictwie wielkopolskim tego czasu $^{68}$.

Karol Marks nie bez racji pisał też o ,idiotyzmie życia wiejskiego”. Z jednej strony byli liberałowie i pozytywiści, którym zamożność i majątek ułatwiały optymizm, z drugiej - konserwatyści. Życie miejskie miało wielbicieli i zażartych przeciwników wśród artystów. Jeszcze Schiller kochał życie miejskie, bo uważał miasto za miejsce wyższej kultury, wolności, aktywności i ruchu. Jednak uważał, że świat rustykalny też ma swoje niewątpliwe uroki ${ }^{69}$.

$\mathrm{Z}$ drugiej strony szybkie zmiany i innowacje burzyły dotychczasowe tradycje. Znikała - albo schodziła na drugi plan - stabilna i żyjąca spokojniej oraz posiadająca pewne wsparcie gminy i junkra rodzina wiejska. Cywilizację

${ }^{68}$ P. Matusik, „Nadeszła epoka przejścia”. Nowoczesność w piśmiennictwie katolickim poznańskiego 1836-1871, Poznań 2011, s. 184-185; Z. Ostrowska-Kłębowska, Architektura pałacowa drugiej połowy XVIII wieku w Wielkopolsce, Poznań 1969, s. 296-297.

${ }^{69}$ J. Kuczynski, Geschichte des Alltags..., s. 173. 
industrialną krytykowali Thomas Carlyle i John Ruskin, przeciwstawiając jej średniowiecze - jako okres prostego i pięknego oraz szczęśliwego życia ${ }^{70}$. Wrogiem industrializacji był niemiecki konserwatywny historyk kultury Wilhelm Heinrich Riehl (1823-1897), którego poglądy na rodzinę zawarte przede wszystkim w pracy Die Familie oddziaływały jeszcze w III Rzeszy i który z perspektywy obyczajowej degrengolady wielkich metropolii, będącej skutkiem masowej kultury i industrializacji, mówił o „wodogłowiu nowoczesnej cywilizacji”. Rewolucja 1848 roku uwiarygodniła scenariusze ludowej rewolty i wystraszyła mieszczaństwo nie na żarty. W kolejnych dziesięcioleciach mieszczanie brali już pod uwagę możliwość masowej przemocy ludu, co rzutowało na ich ocenę sytuacji i sprzyjało słuszniejszym niż dotąd polityczno-społecznym decyzjom.

Riehl słusznie też wskazywał, że wspólnota wiejska oparta o przechodzący z pokolenia na pokolenie dom rodzinny, gdzie żyć łatwiej, zamieniona została w przemysłowym mieście w izolowaną samotność jednostki, która znikąd nie może liczyć na wsparcie. Konserwatyzm Riehla polegał jednak nie tylko na chwalebnej trosce o stabilność rodziny, ale też na tradycjonalistycznych przekonaniach o podziale ról płciowych w związku, społeczeństwie i polityce. Robotników się bał i uważał za zagrożenie dla całego społeczeństwa, podobnie jak kosmopolityzm. Częściowo słusznie, ale częściowo histerycznie i przesadnie atakował wielkie miasto za wszystko, także za grzechy, których tam nie było, jak na przykład upadek sztuki i muzyki ${ }^{71}$.

Konserwatysta Riehl był w większości ocen krytycznych wobec współczesności, w tym miast i niehumanitarnych, szkodliwych dla rodziny warunkach życia ludu, bliźniaczo podobny do socjalisty Fryderyka Engelsa i papieża Leona XII. Jedynie liberałowie zatopieni byli w futurologicznych pełnych entuzjazmu i nawet ekstazy rojeniach i fantazjach, mających silne podglebie technologiczne i przekonanie, że wszyscy wartościowi ludzie już odnieśli sukces.

Nie tylko Riehl, ale i konserwatyści powszechnie z nostalgią wspominali wyidealizowane życie wiejskie i włościan, powodzeniem cieszyła się agrarna romantyka i historia. Chętnie wracano do historii codzienności sprzed industrializacji i celebrowano jej pamiątki. Ślązak Karl Jentsch w 1913 roku z typowym dla tego nurtu dosyć czułostkowym sentymentalizmem pisał, że człowiek wyrzucony został z „zielonych krajobrazów na kamienną pustynię”, na „dymiące,

\footnotetext{
${ }^{70}$ W. Rybczyński, Dom. Krótka historia idei, Gdańsk-Warszawa 1996, s. 30-31.

${ }^{71}$ J. Reulecke, Die Mobilisierung..., s. 26; J. Kuczynski, Geschichte des Alltags..., s. 186-187.
} 
cuchnące, sczerniałe hałdy węgla". Rolnik wykonujący zindywidualizowaną, przyjazną i zdrową dla człowieka, zróżnicowaną i bliską przez to sztuce (rzemieślnicy) pracę na powietrzu i na łonie przyrody przeciwstawiany był robotnikowi. Ten pracował jednostajnie i wykonywał proste, ogłupiające czynności przy maszynie. Podobnie architekt Paul Schulze-Naumburg w 1904 roku obwieszcza1 zagrożenie narodowe wsi ze strony miasta i jego stylu życia. Uwagę krytyków zwracała wątła postura, chorowitość i bieda mieszkańców miast, przede wszystkim robotników, mówiono wręcz o fizycznej i psychicznej degeneracji. Jej przejawem miała być wysoka przestępczość w wielkich miastach, rozwój prostytucji, alkoholizmu i masowe występowanie chorób płciowych oraz upadek obyczajów w ogóle, a także rodziny, na koniec zaniedbanie wychowania młodzieży. Krytycy ubolewali nad spadającą zdolnością moralną i osobowościową młodzieży do służby wojskowej ${ }^{72}$. Wohnungsfrage wtapiało się jako istotny element krytyki cywilizacji zarówno ze strony konserwatystów świeckich, jak i Kościoła katolickiego, którego oddziaływanie w Prusach na ludność było znaczące. Identyczne wypowiedzi słychać z ówczesnej Francji, gdzie po 1850 roku stwierdzano narastający odsetek zwolnień od służby wojskowej z powodu cherlawego zdrowia, wad wrodzonych, kalectwa, niedomagań psychicznych. Mnożyły się histeryczne opinie lekarzy o degeneracji populacji i zwyrodnieniach prowadzących do zbrodni i przestępstwa coraz większej liczby mieszkańców miast. Tkaczy lyońskich nazywano „małymi wynędzniałymi ludzikami o kabłąkowatych nogach”. Robotników z Lille przedstawiano jako „bladych osobników o miękkim i zwiotczałym ciele, okaleczonym na wszystkie możliwe sposoby”. Mówi się następnie o „opłakanym zwyrodnieniu rasy"73. Temat degeneracji ludu i dziedzicznych obciążeń coraz bardziej rozwijał się z biegiem XIX wieku. Pisano o dziedziczeniu alkoholizmu, kretynizmu, gruźlicy, syfilisu etc..$^{74}$

Fundamentalnym i do dzisiaj robiącym wielkie wrażenie dokumentem był encyklika papieża Leona XII Rerum novarum ${ }^{75}$. Na samym wstępie mowa jest o „napływie bogactwa do rąk niewielu, przy równoczesnym zubożeniu mas” oraz pogorszeniu obyczajów, co doprowadziło do tego, że „walka społeczna zawrzała”.

\footnotetext{
${ }^{72}$ J. Kuczynski, Geschichte des Alltags..., s. 120-123; U. Frevert, Krankheit als politisches Problem..., s. 186.

${ }^{73}$ G. Vigarello, Historia zdrowia i choroby..., s. 200-201.

${ }^{74}$ Tamże, s. 200-201.

${ }^{75}$ Leon XII, Rerum novarum, http://www.nonpossumus.pl/encykliki/Leon_XIII/rerum_novarum.
} 
Mimo bardzo licznych takich stwierdzeń papież lewicę uważał, za „,hytrych wichrzycieli”, którzy chcą wykorzystać realne problemy dla swoich podstępnych celów. Jak zauważał papież, zniknęła też tradycyjna w feudalizmie ochrona religii i jej instytucji oraz organizacji, a także pozbawienie znacznej części majątku, a robotnicy zostali „wydani na łup nieludzkości panów i chciwości współzawodników. Zło powiększyła jeszcze lichwa żarłoczna”. „Garść możnych i bogaczy nałożyła jarzmo prawie niewolnicze niezmiernej liczbie proletariuszy”.

Encyklika była więc skierowana z jednej strony przeciwko liberałom, ale z drugiej przeciwko lewicy, dążącej do zniesienia własności prywatnej, zbyt zlaicyzowanej i ateistycznej, aby ją zaakceptować. Jak pisał Leon XII, „należy szybko i skutecznie przyjść z pomocą ludziom z warstw niższych, którzy znajdują się w stanie niezasłużonej, a okropnej niedoli." Papież ostro krytykował bogaczy, którzy traktują pracownika nie jak człowieka, ale narzędzie zysku, oceniają wartość człowieka według posiadanych pieniędzy i nie szanują jego osobistej godności. Ten stan rzeczy nazywał „,bezwstydem”. Płaca powinna być odpowiednia do kosztów utrzymania rodziny, a nie brać się z nędzy pracownika, który gotów jest pracować za każde wynagrodzenia, aby tylko utrzymać przy życiu potomstwo i rodzinę. Brak odpowiedniej, adekwatnej do kosztów życia płacy nazywał papież „zbrodnią wołającą o pomstę do nieba”. Płaca nie może więc wynikać jedynie ze stosunków rynkowych, ale brać również pod uwagę koszty utrzymania rodziny na skromnym, ale nieuwłaczającym godności poziomie. Tak więc robotnika trzeba godziwie opłacić, a ten z kolei winien wstrzymać się od gwałtów i rozruchów wobec pracodawcy. Godziwa płaca spowoduje, pisał Leon XII, że pracownik nie będzie zmuszony do porzucenia kraju i emigracji. Papież wspierał związki zawodowe, bo człowiek osamotniony pozbawiony jest wsparcia i wspólnota zgodna jest $\mathrm{z}$ tradycją biblijną. W encyklice widać jednak było zarazem wyraźną niechęć do interwencjonizmu państwowego, etatyzmu i szerzej zakrojonych działań. Płaca robotnika powinna być wystarczająca do utrzymania rodziny i wynajęcia skromnego, ale umożliwiającego godne życie mieszkania.

Z kolei Fryderyk Engels w 1887 roku pisał o kwestii mieszkaniowej w odniesieniu do Niemiec i Prus w sposób zdecydowanie łagodniejszy od Leona XII, bo niezawierający tego oburzenia i emocji, a jedynie suchą analizę sytuacji. Leon XII chciał „zbliżenia bogatych i ubogich”, a Engels twierdził, że jest to utopijna mrzonka, a jedynym lekarstwem jest rewolucja. Jak zauważył, na Niemcy „spłynęło właśnie błogosławieństwo miliardów francuskich, pobudowano twierdze 
i koszary"76. Nic to jednak nie zmieniło w kwestii mieszkaniowej. Engels mówił o powszechnym ,głodzie mieszkaniowym”, co tłumaczył zasadnie i nie robił wielkiego odkrycia: „Z jednej strony masy robotników rolnych przenoszą się nagle do wielkich miast przekształcających się w ośrodki przemysłowe; $\mathrm{z}$ drugiej strony rozplanowanie miast starszego typu już nie odpowiada potrzebom nowopowstającego wielkiego przemysłu i komunikacji, której ten wymaga; poszerza się ulice i przebija się nowe; przeprowadza się środkiem miast koleje żelazne (...) Właśnie ów ostry głód mieszkaniowy będący oznaką dokonywającej się w Niemczech rewolucji przemysłowej powodował, że prasa była wówczas pełna rozpraw o kwestii mieszkaniowej" ${ }^{77}$. Słowa Engelsa odnosiły się przede wszystkim do najbardziej uprzemysłowionej Nadrenii i Berlina. Jak zauważał na temat Berlina, budownictwo mieszkaniowe spowalniało wzrost cen gruntów i czynszów w szybko rosnących wielkich miastach. „Spotyka to przede wszystkim położone w centrum mieszkania robotnicze, za które komorne nawet przy największym ich przeludnieniu, nie może nigdy lub tylko rzadko przekraczać pewnego maksimum. Burzy się je więc i buduje na ich miejscu sklepy, składy towarów lub gmachy publiczne"78. W rezultacie robotnicy wypychani byli coraz bardziej na obrzeża miast, gdzie były tańsze grunty ${ }^{79}$.

Z punktu widzenia warunków mieszkaniowych, zauważa autor, w kapitalizmie industrialnym nastąpiło pogorszenie warunków bytowania klas niższych. Robotnicy w masie stracili pewność dachu nad głową. Z tej perspektywy los chłopa pańszczyźnianego był bardziej pewny. „Tkacz ręczny, który prócz krosna posiadał swój własny domek, ogródek i pólko, był - przy swej całej biedzie i ucisku politycznym - człowiekiem spokojnym i zadowolonym”. I dalej: „Że zaś położenie klasy robotniczej od czasu wprowadzenia produkcji kapitalistycznej na wielką skalę się pogorszyło, o tym powątpiewa tylko burżuazja"80. Konserwatywne czy proudhonowskie pomysły powrotu wszystkich na wieś były jednak absurdalne - stwierdzał słusznie Engels - ponieważ feudalne stosunki i praca

\footnotetext{
${ }^{76}$ F. Engels, W kwestii mieszkaniowej, w: tegoż, Dzieła wybrane, t. 1, Warszawa 1949, s. 514.

77 Tamże, s. 515.

${ }^{78}$ Tamże, s. 526.

${ }^{79}$ Z. Maćkowiak, T. Popow, Klasycy marksizmu o kwestii mieszkaniowej, w: 90 lat spółdzielczości mieszkaniowej..., s. 104.

${ }^{80}$ F. Engels, W kwestii mieszkaniowej..., s. 530.
} 
ręczna oznaczały bardzo niską produktywność, niewolę i okresowe masowe klęski głodu.

Jak wspominałem, Fryderyk Engels paradoksalnie tę sytuację oceniał pozytywnie, jako posiadającą potencjał rewolucyjny i pchający stosunki społeczne naprzód. Identyczne jednak zagrożenia dostrzegała konserwatywna prawica. Właśnie brak dachu nad głową być miał jednym z ważnych wyzwalaczy rewolucji: „stłoczony w wielkich miastach proletariat jest zdolny dokonać tego wielkiego przekształcenia społecznego, który położy kres wszelkiemu panowaniu i wyzyskowi klasowemu"\$1.

Engels wskazywał też na niebezpieczeństwa sanitarne współczesnych mu dzielnic biedy: ,stanowią wylęgarnię wszelkich epidemii nawiedzających od czasu do czasu nasze miasta. Cholera, tyfus, gorączka tyfoidalna, ospa i inne choroby epidemiczne szerzą swe zarazki w zakażonym powietrzu i zatrutej wodzie tych dzielnic robotniczych". Epidemie szerzące się w dzielnicach biedy przenoszą się potem na bogatych: „Ci więc nie mogą pozwalać sobie na przyjemność bezkarnego hodowania chorób epidemicznych wśród ludu roboczego - następstwa tego odbijają się i na nich, a anioł śmierci sroży się między kapitalistami z tą samą bezwzględnością, co i wśród robotników (...). Zakładano stowarzyszenia, pisano książki, kreślono szkice projektów, omawiano i wydawano ustawy, aby zasypać źródła wciąż powracającej zarazy. Stosunki mieszkaniowe robotników zostały zbadane i podjęto próby zaradzenia najbardziej jaskrawym ich złym stronom"82. Jak stwierdzał, za poprawę sytuacji w Niemczech i Prusach zabrano się później niż w Anglii, ale o wiele solidniej. Generalnie jednak dominowały paliatywy w rodzaju ociekających lepką i obłudną dobrą wolą frazesów i filantropii w rodzaju czasopisma „Związku popierania pomyślności klas pracujących w Prusach". Wielu analityków zrzucało też obłudnie winę na samych robotników wprawdzie zarabiają za mało i nie stać ich na dach nad głową, ale z drugiej strony korzystają z alkoholu i tytoniu i nie oszczędzają należycie, dzięki czemu mogliby mieć komorne na coś lepszego niż niezdrowe, wilgotne, ciemne nory, w których mieszkali. Jak zauważył Engels, eksperci nie chcą przyznać, że pijaństwo nie jest przyczyną, ale jak od stuleci - skutkiem złej sytuacji, „tak samo koniecznym jak tyfus, przestępstwa, robactwo, egzekucje sądowe i inne choroby społeczne (...). Zresztą to już mój stary nauczyciel z szkoły powszechnej mówił: pospólstwo

\footnotetext{
${ }^{81}$ Tamże, s. 531, 533.

${ }^{82}$ Tamże, s. 544.
} 
idzie do szynku, a dystyngowani do klubu, a że ja tu i tam bywałem, więc prawdę tych słów potwierdzić mogę"

W stosunku do Prus uczynił Engels bardzo osobliwe i znamienne uwagi. Jak pisał, konserwatyści tamtejsi twierdzą, że nie rządzi tam burżuazja i państwo jest w znacznym stopniu od niej niezależne, dzięki czemu może jeszcze zrobić wiele dobrego: „państwo jest instytucją do pewnego stopnia niezależną i unoszącą się ponad społeczeństwem i właśnie dlatego reprezentuje ono zbiorowe interesy społeczeństwa, nie zaś interes jednej tylko klasy. Takie państwo może w istocie uczynić to i owo, czego nie może uczynić państwo burżuazyjne" ${ }^{84}$. Engels uważał jednak, że w Niemczech i Prusach nie rządzi całe społeczeństwo, ale wielka własność ziemska, ze słabą jeszcze politycznie burżuazją, ale za to rozwiniętym i bardzo świadomym proletariatem: „w nowoczesnej bonapartystowskiej monarchii rzeczywista władza państwowa spoczywa w rękach odrębnej kasty oficerskiej i urzędniczej, która w Prusach uzupełnia swe kadry po części sama z siebie, po części z drobnej szlachty majorackiej, rzadziej z wielkiej arystokracji, a w najmniejszej cząstce z szeregów burżuazji”85.

Engels krytykował też tzw. utopijnych socjalistów za pomysły, aby wszyscy robotnicy stali się właścicielami swoich mieszkań przez comiesięczną spłatę w postaci komornego aż do przejęcia lokalu na własność. Autor wskazywał, że w sytuacji częstej zmiany pracy i miejsca zamieszkania w kapitalizmie pomysł powszechnej stopniowo wykupywanej własności mieszkań jest całkowitą utopią: „jakiś Piotr pracuje dajmy na to, w fabryce maszyn w Berlinie. Po roku staje się on właścicielem $1 / 15$ swojego jednoizbowego mieszkanka na piątym piętrze gdzieś w okolicach Bramy Hamburskiej. Traci robotę i wkrótce potem znajduje się w podobnym mieszkaniu ze wspaniałym widokiem na podwórko na trzecim piętrze w Pothofie w Hanowerze...” Po tym następują kolejne przeprowadzki do Monachium na skutek strajków i dalej, co, jak pisze autor, w kapitalizmie industrialnym jest zjawiskiem częstym ${ }^{86}$. Szkołę Gustawa Schmollera, która opowiadała się podobnie za uczynieniem robotników właścicielami mieszkań, Fryderyk

\footnotetext{
${ }^{83}$ Tamże, s. 548-549.

${ }^{84}$ Tamże, s. 568.

${ }^{85}$ Tamże, s. 569.

${ }^{86}$ Por. T. Nipperdey, Deutsche Geschichte 1866-1918..., s. 142-145.
} 
Engels nazywał „burżuazyjnym i drobnomieszczańskim socjalizmem”, „Kathedersozialisten" $"$.

Jeżeli chodzi o optymistów kapitalistycznego wzrostu, symboliczną, wielką i świetlaną oraz liberalną wizję przyszłości kapitalizmu stanowił Kryształowy Pałac. Była to wielka konstrukcja z żelaza i szkła projektu Josepha Paxtona mierząca 560 metrów długości i 125 szerokości, tak wielka, że w jej wnętrzu mieściły się całe drzewa. Wzniesiona została z okazji pierwszej Wielkiej Wystawy Światowej w Londynie w 1851 roku, która miała stworzyć wizję przyszłości jako Ziemi Obiecanej właśnie dla mas, ponieważ ukazywała możliwości produkcji masowej, przeznaczonej dla zwykłych ludzi. Wystawę dla 15 tys. wystawców zwiedziło sześć milionów ludzi. Potem przyszły kolejne, związane z fascynacją Zachodu postępem technicznym. Co ciekawe, znalazł się tutaj też angielski modelowy dom dla klasy pracującej ${ }^{88}$. Pozytywistyczna fascynacja postępem technicznym i nadzieje na powszechny dobrobyt widoczne były również w popularnych jeszcze długo w XX wieku powieściach Juliusza Verne’a. Okręt podwodny kapitana Nemo płynie więc np. wzdłuż kabla telegraficznego łączącego Amerykę z Europą, który był ogromnym przedsięwzięciem tych czasów. Akcja książki 20000 mil podmorskiej żeglugi zaczynała się w roku 1866 ${ }^{89}$. Jak pisze Jedlicki, o ile wszakże maszyna była chlubą Anglii, to miasto jej wstydem. Obraz życia miasta Coketown z drugiej połowy XIX wieku z powieści Karola Dickensa Ciężkie czasy był przerażający, ale prawdziwy, i stał się negatywnym symbolem nędzy całej industrialnej Europy tego czasu. Sam zwrot „miasto przemysłowe” kojarzył się jednoznacznie ze smrodem wyziewów, stukotem maszyn parowych, monotonią identycznych ulic z czerwonej cegły, mgłą zmieszaną z dymem i bezustannym deszczem ${ }^{90}$.

Konserwatyzm był więc krytyczny, ale dominowała leseferystyczna wiara w wolną konkurencję, socjaldarwinizm i utylitaryzm oraz wrogość wobec wszelkiego planowania, regulacji prawnych i kontroli państwa nad mieszkaniami i całą urbanistyką. Narastający wraz z błyskawicznym rozrostem chaos miejskiej tkanki, dotykający przecież przede wszystkim biedotę, uznano za stan naturalny,

\footnotetext{
${ }^{87}$ F. Engels, W kwestii mieszkaniowej..., s. 517.

${ }^{88}$ J. Jedlicki, Świat zwyrodniały. Lęki i wyroki krytyków nowoczesności, Warszawa 2000, s. 99-100; S. Parissien, Historia wnętrz. Dom od roku 1700, Warszawa 2010, s. 116-117.

${ }^{89}$ H.R. Lottmann, Juliusz Verne, Warszawa 1999.

${ }^{90}$ J. Jedlicki, Świat zwyrodniały..., s. 104-105; L. Mumford, Die Stadt. Geschichte und Ausblick, Köln 1963, s. 520-521; U. Eco, Historia brzydoty, Poznań 2007, s. 335-337.
} 
z którego wydobędą się tylko siły zdrowe i warte przetrwania. Wrogość wzbudzały wszelkie działania wspólnotowe, ingerencje komunalne i państwowe ${ }^{91}$. Przy tym - obiektywnie - poziom życia ludu pozostawał bardzo niski, nie tylko w Prusach, ale przez całe Niemcy, Francję, aż do Dublina i Glasgow. Dominowała wszędzie czynszówka, w której na rodzinę przypadała jedna izba, z jednym łóżkiem, w którym spało kilka osób - przemieszanych dorosłych i dzieci. Generalnie dominowały brudne, pełne nieczystości ulice, ciemne podwórka, małe okna i brak światła i ciepła, brak zieleni, parków i placów zabaw dla dzieci. Tak wyglądał świat europejskiej industrializacji, w której Berlin i Prusy się nie wyróżniały, a jeżeli już - to na plus ${ }^{92}$.

\section{Krytyka architektury mieszczańskiej}

Arnold Hauser dawno temu zwracał uwagę na ogromne przyśpieszenie zmian mód artystycznych i kulturalnych pod koniec XIX wieku. Zaczęło się znane i dzisiaj sztuczne tworzenie popytu przez przemysł konsumpcyjny. Centrami rozwoju sztuki i architektury stały się wielkie miasta. Jak pisze Hauser, impresjonizm ma charakter miejski ${ }^{33}$. Tradycyjna sztuka jednak trwała, a mody architektoniczne powtarzały i mieszały style minionych stuleci. Dopiero pierwsza wojna światowa przyniesie wielką zmianę i odrzucenie tradycji wraz z nadejściem dadaizmu, będącym protestem przeciwko kulturze mieszczańskiej, która do wojny doprowadziła ${ }^{94}$. Tymczasem jednak, u schyłku wieku XIX, Berlin był najszybciej rozwijającym się miastem świata, a za tym szły i ogromne architektoniczne dysproporcje; wielki przepych oraz monstrualność form, mocno zalatujące nuworyszowskim kiczem, ale i ogromne obszary zwykłej, brzydkiej nędzy. Takie są opinie współczesnych historyków sztuki. Theodor Fontane w 1872 roku pisał o braku smaku, formy i wyczucia w architekturze Berlina. Nie podobały mu się jednak nie tylko koszary czynszowe, ale i domy bogatego mieszczaństwa. Style poszczególnych kamienic, zdaniem tego pisarza, ale i wielu innych historyków sztuki i architektów, poczynając od końca wieku XIX, stanowiły niezborną, eklektyczną mieszaninę klasycyzmu, gotyku, baroku, najczęściej pompatyczną i przeładowaną ozdobnikami i sztukateriami. Miały przede wszystkim oszałamiać bogactwem

\footnotetext{
${ }^{91}$ L. Mumford, Die Stadt..., s. 526-528.

${ }^{92}$ Tamże, s. 537, 541-542.

${ }^{93}$ A. Hauser, Spoteczna historia sztuki i literatury, t. 2, Warszawa 1974, s. 316-317.

${ }^{94}$ Tamże, s. 366.
} 
nowobogackich i robić wrażenie potęgi. Historyk sztuki Peter Feist pisze o architektonicznej hipertrofii, która demonstrowała władzę, potęgę i zamożność elit, jak o czymś trwałym i stabilnym. Zdaniem tego autora analogiczna była francuska pompatyczność II cesarstwa. Nie tylko w architekturze, ale i w całej plastyce, rzeźbie i malarstwie widoczny był zbytek, sztuczność, przesada, próba olśnienia bogactwem, dominacja wątków heroicznych albo sentymentalnych.

Jak stwierdzał z niesmakiem liberalny historyk architektury i sztuki Karl Scheffler w 1931 roku, nigdzie nie było tyle wieżyczek, kolumn, pilastrów, ornamentów z gipsu, gzymsów, balustrad, kartuszy, owoców, głów lwów, figuratywnych alegorii, marmurów, pałacowych okien, książęcych portali. Szlachetna prostota klasycyzmu należała w budownictwie do rzadkości, a eklektyzm typu Schinkla z początku XIX wieku był wielkim przeżyciem artystycznym wobec czystego „chamskiego parweniuszostwa” (pöbelhaft) epoki grynderskiej. Fontane odnotowywał jednak tylko początki niedobrego eklektycznego bezguścia, które nasiliły się w latach 80 . i 90. Jedynym regulatorem estetycznym miasta była ekonomia i spekulacje gruntowe oraz przepisy budowlane ${ }^{95}$.

Podobnie wypowiadał się w 1907 roku architekt i wielbiciel stylu angielskiego (Landhausstil), Hermann Mathesius ${ }^{96}$. Uwagi jego dotyczą jednak przeznaczonych dla zamożnych mieszczan kamienic czynszowych (Mietshaus). Znacznie gorsza była sytuacja z koszarami czynszowymi (Mietskaserne) przeznaczonymi dla robotników, których stan krytykował Gustaw Schmoller ${ }^{97}$. Twierdził on, że doprowadzenie klas niższych do poziomu barbarzyńców i bestii obróci się wcześniej czy później przeciwko elitom, zarówno przez epidemie, jak i rewolucję, powinny więc one obudzić się z drzemki (Schlummer), aby temu przeciwdziałać ${ }^{98}$.

${ }^{95}$ J. Kuczynski, Geschichte des Alltags..., s. 212-213; P.H. Feist, Geschichte der deutschen Kunst..., s. 258; T. Nipperdey, Deutsche Geschichte 1866-1918..., s. 139.

${ }^{96}$ Tamże, s. 213; „Überall ist der billigste Surrogatschwindel mit Behagen entfaltet, und es herrscht allein das Bestreben, dem Urteilslosen durch Prunk der Ausstattung zu imponieren".

${ }^{97}$ Tamże, s. 214. Znany konserwatysta Gustaw Schmoller pisał: „Die Zustände sind so entsetzlich, daß man sich nur wundern muß, daß die Folgen nicht noch schlimmere geworden sind. Nur weil ein großer Teil dieser Armen bis jetzt einen Schatz guter Sitte, kirchlicher Überlieferung, anständiger Empfindungen aus früherer Zeit mit in diese Höhlen gebracht hat, ist das Äußerste noch nicht geschehen".

${ }^{98}$ Tamże, s. 215; B. Baranowski, Wyposażenie wnętrz..., 431. 


\section{Mieszkania bogatego mieszczaństwa i szlachty}

Willa mieszczańska w okresie cesarstwa mogła składać się z około 20 pokoi i coraz częściej wznoszona była wśród zieleni, ogrodów i parków na przedmieściach, w oddali od zgiełku i dymu fabrycznych kominów. Mieszkanie na jednym piętrze miało zwykle 4-10 izb mieszkalnych. Klasa średnia w Düsseldorfie w okresie 1880-1890 zajmowała mieszkania o powierzchni ok. $200 \mathrm{~m}^{2} \mathrm{w} 10$ pokojach. Dla okresu 1901-1914 zarysowała się tendencja spadkowa do $170 \mathrm{~m}^{2}$ na 8 pokojach. Badania wśród zachodnioniemieckiej inteligencji pruskiej wykazały, że zamieszkiwała mieszkania 6-pokojowe. Profesorskie mieszkania zawierały zawsze wielką bibliotekę, co zmniejszało mobilność tej grupy. W klasie średniej występowało też oczywiście duże zróżnicowanie. Radca rejencji albo nauczyciel gimnazjum, którego pozycja była i tak w porównaniu do Polski niezwykle wysoka, był już bardzo zadowolony, kiedy zajmował więcej niż czteropokojowe mieszkanie ${ }^{99}$.

O pozycji mieszkańców świadczył „dobry adres” w odpowiedniej dzielnicy i przy właściwej ulicy, a następnie także piętro zajmowane w kamienicy. Im wyżej, tym gorzej. Nierzadko mieszkania na 1-2 piętrze były 7-8-pokojowe, a na 3-4 piętrze 3-4-izbowe. Ważna była też odpowiednio bogato zdobiona fasada, a następnie wejście, portal i klatka schodowa, czy schody były reprezentacyjne, czy na ścianach marmury, czerwone chodniki na schodach itd. Thomas Nipperdey wprost określa ten wielkopański styl demonstracyjnej manifestacji zamożności „feudalnym”. Klasy wyższe nie życzyły sobie kontaktu z niższymi, dla których było wejście od podwórza. Zamożność mieszkańców kamienicy oceniało się też po jej architektonicznym bogactwie, braku monotonii i częstej asymetryczności fasady. Zamożni mieszkali często w willach na przedmieściu, najbogatsze pałace, jak Kruppa, należały do rzadkości. Salon zamożnego mieszczaństwa mógł mierzyć nawet $60 \mathrm{~m}^{2} \mathrm{z}$ kolumnadami dzielącymi i wzbogacającymi przestrzeńn ${ }^{100}$.

Francuska historyczka Michelle Perrot zauważa podobieństwo stylu mieszczańskiego mieszkania w Berlinie, Wiedniu i Sankt Petersburgu na przełomie XIX i XX wieku. Składało się na to zbliżenie występującego w różnych miejscach eklektyzmu architektonicznych stylów, pewnego praktycyzmu i funkcjonalności

${ }^{99}$ A. von Saldern, Im Hause, zu Hause..., s. 173, 178; B. Fuhrmann, W. Meteling, B. Rajkay, M. Weipert, Geschichte des Wohnens von Mittelalter..., s. 110-111; T. Nipperdey, Deutsche Geschichte 1866-1918..., s. 139; W.H. Hubbard, Familiengeschichte. Materialien zu deutschen Familie seit dem Ende des 18. Jahrhunderts, München 1983, s. 230-242.

100 Tamże, s. 174, 177; T. Nipperdey, Deutsche Geschichte 1866-1918..., s. 138-139. 
pomieszanej z arystokratyczną nostalgią, ambicjami i pretensjami do sfery wyższej. Ciągle widać było ślady wzorów budowy i wnętrz mieszkalnych pałaców i salonów z XVIII wieku ${ }^{101}$. Oczywiście mieszkania drobnomieszczaństwa były odpowiednio prostsze i skromniejsze, znacznie rzadziej rozdzielone były funkcje pomieszczeń, jednak zawsze starano się o posiadanie pianina, jako symbolu statusu, oraz salonu (gute Stube) z obowiązkową sofą, obrazem na ścianie, stołem i fotelami ${ }^{102}$. Jeżeli chodzi o meblarstwo, wspomnieć trzeba o swarzędzkiej fabryce mebli, która meblowała mieszkania poznańskiego mieszczaństwa meblami cieszącymi się renomą i znanymi z wysmakowania i dobrego gustu artystycznego ${ }^{103}$.

Walter Benjamin wspominał swoje mieszczańskie berlińskie dzieciństwo w zamożnym domu mieszczańskim przeładowanym ciężkimi draperiami i bogatymi zasłonami. Prawdę mówiąc, był to styl pompatyczny i ciężki, neobarokowy, z licznymi ozdobnikami, służący zrobieniu wrażenia bogactwa i podkreślający różnice wobec biedy robotników. Benjamin pisał o pozbawionym zwykłej wygody „bezdusznym przepychu umeblowania”104. Jak pisał, mieszczański styl ubierania się oraz wnętrz mieszkalnych był częścią jednolitego mieszczańskiego stylu życia. Było tu miejsce na obowiązkową palmę, landschaft z Alp z małym uśmiechniętym Alpejczykiem, a całość kojarzyła mu się ze skrzyżowaniem „damskiego buduaru z izbą tortur” ${ }^{05}$. Powszechne były popiersia postaci historycznych, fortepiany oraz biblioteczki, podkreślające wykształcenie rodziny, oraz witrynki, w których eksponowano pamiątki, porcelanę, kryształy. Znajdowały się tu też akcenty orientalne: perskie dywany i otomany, ciężkie kilimy i wiszące na ścianach kaukaskie sztylety. W Ulicy jednokierunkowej Benjamin tak pisał o tym zamożnym dziesięciopokojowym mieszczańskim mieszkaniu lat dziewięćdziesiątych XIX wieku: ,zawierające ogromne przepełnione rzeźbieniami kredensy, pozbawione słońca kąty ze stojącą tam palmą, wykusz oszańcowany balustradą i długie korytarze ze śpiewającym płomieniem gazowym nadaje się do zamieszkania tylko dla nieboszczyków"106. Tak samo wyglądały mieszkania zamożnego mieszczaństwa paryskiego: „spojrzenie gubiło się wśród wydętych

${ }^{101}$ M. Perrot, Sposoby zamieszkiwania..., s. 317-318.

102 T. Nipperdey, Deutsche Geschichte 1866-1918..., s. 140-141.

${ }^{103}$ B. Baranowski, Wyposażenie wnętrz..., s. 436.

104 W. Benjamin, Ulica jednokierunkowa, Warszawa 2011, s. 30.

105 Tenże, Berlińskie dzieciństwo..., s. 10; tenże, Pasaże..., s. 248; A von Saldern, Im Hause, zu Hause..., s. 180.

${ }^{106}$ W. Benjamin, Ulica jednokierunkowa..., s. 29-31. 
zasłon i pękatych poduszek, w których stojące zwierciadła otwierały się przed wzrokiem gości perspektywami kościelnych portali, a kozetki przybierały kształt gondol osrebrzonych gazowym światłem ze szklanej kuli niby blaskiem księżyca”107. A gdzie indziej: „Czym była jadalnia z jej dusznym misterium, zgłębił tylko ten, kto zdołał sobie wyjaśnić dysproporcję drzwi i sięgającego do sufitu szerokiego, masywnego kredensu (...). Sprzątaczka, która opróżniała wszystko wokół nie potrafiła się z nim uporać. Mogła tylko zdjąć i ustawić w sąsiednim pokoju srebrne wiaderka i wazy, delfickie wazy i majoliki, urny z brązu i szklane puchary, stojące w niszach kredensu i pod jego baldachimami w kształcie muszli, na jego tarasach i estradach, między jego portalami i przed jego panelami. Wysokość na jakiej tronowały pozbawiała je wszelkiej praktycznej przydatności. Dlatego kredens zasadnie przypominał górę świątynną (...). Przedmioty wszakże, które tam się znajdowały, nie występowały po dziesięć, nie, w powieleniu po dwadzieścia lub trzydzieści. I kiedy tak patrzyłem na te długie, długie rzędy łyżeczek do kawy i podstawek pod noże, nożyków do owoców i widelców do ostryg, z przyjemnością widoku obfitości zmagał się lęk, że nasi goście będą wyglądać tak samo jednakowo jak nasze sztućce"108.

Musimy sobie uświadomić, jak dalece elity i klasa średnia XIX stulecia, nie tylko szlachta, zanurzone były w historii i z nią związane. Dopiero na początku XX wieku modna stała się nie tylko secesja, ale pojawił się też modernizm, który odrzucał historię w architekturze i wnętrzu mieszkalnym jako balast. Architekt C.F.A. Worsey w 1893 roku proponował ,pozbycie się olbrzymiej ilości bezużytecznych dekoracji i wyrzucenie tych ozdóbek, które obrzydzają nasze meble i sprzęty oraz zlikwidowanie ilości deseni i kolorów w pokoju" ${ }^{\prime 109}$. Były to jednak dopiero początki zjawiska, którego szczytową formą były nacechowane prostotą projekty naigrywającego się z foteli w stylu Ludwika XVI, Le Corbusiera w wieku XX, chociaż i wówczas znaczna część mieszczaństwa nie podzielała jego gustu i nawet po drugiej wojnie światowej nadal kupowała historyczne meble. Mimo to Thomas Nipperdey odnotowuje jednak na horyzoncie roku 1900 uproszczenie i rozjaśnienie stylu, zmniejszenie natłoku i przeładowania, mniej reprezentacji, więcej praktyczności, a więc nowoczesność i modernizm ${ }^{110}$.

\footnotetext{
107 Tenże, Pasaże..., s. 242.

108 Tenże, Berlińskie dzieciństwo..., s. 130-131.

109 S. Parissien, Historia wnętrz..., s. 208.

110 Tamże, s. 209; T. Nipperdey, Deutsche Geschichte 1866-1918..., s. 140-141.
} 
Salon i sypialnia miały bardziej kobiecy charakter, w związku z czym około 1890 roku powróciła w tych miejscach moda na meble rokokowe, ozdobne, ale lekkie i pełne wdzięku. Meble w jadalni i gabinecie pozostawały jednak wielkie i reprezentacyjne, neobarokowe i mahoniowe. Ich zadaniem było sprawianie wrażenia luksusu. Po 1871 roku istniał też, uważany za narodowy i niemiecki, prąd nowego renesansu w meblarstwie. Historycy sztuki uważają raczej ówczesne wnętrza za wtórne, naśladujące arystokrację, upstrzone mnóstwem bibelotów bezguście ${ }^{111}$. Kobieta, jako pani domu (Hausfrau), uważana była za jego duszę ${ }^{112}$.

Mieszkanie dawało poczucie bezpieczeństwa i było archaicznym pierwotnym schronieniem. Benjamin tak opowiada o mieszkaniu swojej babci: „Jakimi słowy opisać to odwieczne chyba poczucie mieszczańskiego bezpieczeństwa, zapewniane przez to mieszkanie? (...) Dominował tu pewien rodzaj mebli, które $\mathrm{z}$ racji arbitralności, z jaką skupiły w sobie ornamenty wielu stuleci, były tak przesycone sobą i swoim trwaniem, że nie liczyły się z żadnym zużyciem, żadną sprzedażą, ani przeprowadzką (...)"113. Podobnie nostalgiczny był opis mieszkania drugiej babci: „Pokoje tego mieszkania były nie tylko liczne, lecz po części też bardzo obszerne. Aby powitać babcię w jej wykuszu, gdzie wnet obok jej koszyczka z nićmi stawały przed mną owoce i czekolada, musiałem najpierw przebyć olbrzymią jadalnię, a potem sam pokój z wykuszem. Dopiero jednak pierwszy dzień Świąt Bożego Narodzenia pokazywał, do czego właściwie stworzono te pomieszczenia" 114 .

Ważnym elementem umeblowania były szafy, we wnętrzu których ułożone spoczywały ubrania ${ }^{115}$. Mieszczanie meble kupowali często z katalogów, wyjątek stanowił pokój dziecięcy, który jeszcze w końcu XIX wieku, jako mniej ważny, urządzano starymi meblami, których nie chciano jednak wyrzucićn ${ }^{16}$.

Mieszczaństwo w stuleciu XIX stało się w rozwoju cywilizacyjnym klasą wiodącą, jednak, jak wiadomo, pozycja junkrów w Prusach była wysoka, wśród elit rządzących i w armii wiodąca, a mieszczaństwo szlachtę w zakresie

111 A. von Saldern, Im Hause, zu Hause..., s. 180-181.

112 M. Corrodi, Von Küchen und unfeinem Gerüchen. Auf dem Weg zu einer neuen Wohnkultur zwischen Gründerzeit und zweitem Weltkrieg, w: Die Küche. Lebenswelt, Nutzung, Perspektiven, hrsg. v. K. Spechtenhauser, Birkhäuser, Basel i in. 2006.

${ }^{113}$ W. Benjamin, Berlińskie dzieciństwo..., s. 10; tenże, Pasaże..., s. 111-113.

${ }^{114}$ Tenże, Pasaże..., s. 117-118.

115 Tamże, s. 125-127.

${ }^{116}$ A. von Saldern, Im Hause, zu Hause..., s. 179. 
wzorów kulturowych często naśladowało. Wzorem siedziby szlacheckiej był, jak i wcześniej, dwór czy pałac wiejski, połączony z majętnością ziemską i lasem. Las był istotny ze względu na polowania, które stanowiły nadal część stylu życia szlachty. Za tym pojawiały się we wnętrzach trofea myśliwskie świadczące o sprawności bojowej i strzeleckiej junkrów. Szlachcic nie był spokojnym rolnikiem i pasterzem, ale dzielnym i wojowniczym myśliwym. Pałac musiał być zdecydowanie większy i reprezentacyjny oraz być otoczony parkiem. Sposób mieszkania szlachty związany był z całą jej ideologią i stylem życia. Znacznie większą rolę niż w wypadku mieszczan odgrywała tu historia i genealogia, dziedzictwo przodków i konieczność przekazania go przyszłym pokoleniom. Tak więc ściany wypełnione były olejnymi portretami przodków. W późnym wieku XIX, identycznie jak wśród bogatego mieszczaństwa, wnętrza przeładowane były ozdobnikami, panował nadmiar i przepych wymieszanych ze sobą stylów. Plusz był ulubioną tkaniną wnętrz mieszkalnych, wszędzie widać było poduszki i poduszeczki oraz orientalne w stylu dywany i otomany. Kontrastowało to ze skromnością w zachowaniu, a odzwierciedlało zasadę „mehr sein als schein”. Z drugiej strony, w wypadku szlachty na wschód od Łaby, skromność wynikała nierzadko raczej z konieczności i biedy ${ }^{117}$.

\section{Mieszkania robotnicze}

Koniec wieku XIX był okresem ogromnych różnic i dysproporcji w sposobach zamieszkiwania, a poziom życia robotników był niezadowalający i budził wręcz niepokój elit. Poziom pensji robotników w Prusach w 1918 roku był nominalnie dwukrotnie wyższy niż w roku 1871. Faktycznie, jeżeli przyjąć za 100 rok 1895 , to w okresie 1871-1913 nastąpił wzrost pensji realnych z 66 na 125, co wskazuje na niski poziom na początku, a niewysoki na końcu przedziału czasowego. Jeszcze w latach 1907-1908 52\% pensji przeciętnej rodziny robotniczej, wliczając w to pensję żony, przeznaczano na wyżywienie. W 1905 roku rodzina robotnicza na czynsz w ciasnym i przeludnionym mieszkaniu wydawała średnio $17 \%$ swoich dochodów. W małych, ciasnych, słabo ogrzewanych mieszkaniach w Berlinie żyło w 1875 roku 71\%, a w 1905 roku 75\% mieszkańców miasta. Przeludnienie wynikało też z powszechnego podnajmowania miejsc noclegowych i pokojów

${ }^{117}$ B. Fuhrmann, W. Meteling, B. Rajkay, M. Weipert, Geschichte des Wohnens von Mittelalter..., s. 118-119; T. Nipperdey, Deutsche Geschichte 1866-1918..., s. 139. 
jeszcze biedniejszym robotnikom. W Zagłębiu Ruhry 1/4 górników podnajmowała pokoje i łóżka w swoich mieszkaniach ${ }^{118}$.

Max Weber pisał o położeniu klasowym, rozumiejąc przez to zaopatrzenie w dobra, zewnętrzną i wewnętrzną pozycję życiową klasy społecznej, czyli grupy o podobnym położeniu klasowym ${ }^{119}$. Przy ogólnym wzroście poziomu życia, mieszkania robotnicze pozostawały pod koniec XIX wieku bardzo marne. Ciemne, z kiepskim dostępem światła, przepełnione, bez jakiejkolwiek intymności. Michelle Perrot pisze o niższych klasach społecznych w całej Europie „stłoczonych w cuchnących ruderach"120. Pod koniec XIX wieku pojawiło się nie tylko w Prusach, o czym wspominałem, ale i w Europie, na razie teoretyczne pojęcie „minimum mieszkaniowego”, które miało określać wielkość i minimalne wygody lokalu. Także ruch robotniczy w większym stopniu zauważył to zagadnienie i zaczęło się mówić o dostępie do „świeżego powietrza” i ,warunkach zdrowotnych”.

Jeżeli w rodzinie mieszczańskiej dom był centrum życia rodzinnego i umacniania więzi, biedota, na skutek marnych warunków, traktowała mieszkanie jedynie jako sypialnię i przechowalnię i znacznie częściej przebywała poza domem, na podwórzu, na klatce, na ulicy. „Gdzie nie dochodzi słońce, tam zjawia się lekarz”, pisał w 1910 roku berliński przedstawiciel medycyny społecznej, wskazując na bardzo złe warunki zdrowotne nie tylko w wielkomiejskich czynszówkach, ale także w mniejszych miastach niemieckich. Masowym fenomenem były mieszkania zrujnowane i wilgotne. Polityka społeczna szczególnie zafrasowana była rodzinami robotniczymi, gdzie przy 2-3 dzieci występowały ogromne problemy ze stałą pracą i mieszkaniem. Kolejnym masowym problemem był wspólny wynajem pokoju przez kilka osób oraz podział większych mieszkań na małe klitki, tak aby upchać jak najwięcej rodzin. Wśród biednych dominowały mieszkania jednoizbowe. We Wrocławiu w latach 80 . takich mieszkań było $62 \%$, w Chemnitz $70 \%$, ale we Frankfurcie tylko 23\%. Wszędzie w tej grupie dominowały natomiast mieszkania 1-2-pokojowe.

Rodziny niezamożne w miastach mieszkały zwykle w mieszkaniach jednoizbowych albo dwuizbowych wliczając kuchnię. Jeżeli była sypialnia, rodzina uważana była już za dobrze sytuowaną. Własne łóżko było jednak wśród

${ }^{118}$ K.E. Born, Preußen im deutschen Kaiserreich 1871-1918, w: Handbuch der preußischen Geschichte, Bd. 3, hrsg. v. W. Neugebauer, Berlin-New York 2001, s. 75.

${ }^{119}$ M. Weber, Gospodarka i społeczeństwo, Warszawa 2002, s. 228-229.

${ }^{120}$ M. Perrot, Sposoby zamieszkiwania..., s. 321. 
robotników raczej czymś niezwykłym. Berliński lekarz informował, że $2 / 3$ z badanych przez niego 6651 berlińskich dzieci własnego łóżka nie ma. Typowy był mieszkaniec Legnicy Paul Löbe, który pisał, że żyje w jednej izbie z alkową z małym lufcikiem i bez okna. Generalnie umeblowanie mieszkań robotniczych było bardzo ubogie i już szafa na ubrania oraz sofa uważana była za zbytek. Fatalne były warunki tych mieszkań w zakresie urządzeń sanitarnych. Nierzadko na jedną toaletę przypadało 30, 50, a nawet 80 osób ${ }^{121}$. Relacja z Pomorza Tylnego mówi o rodzinie sześcioosobowej w jednej izbie z dwójką małych dzieci i chorym ojcem: ,und dort wurde gewohnt, geschlafen, gekocht und gewaschen - und jetzt diente es auch noch als Krankenstube!"'122

Warunki mieszkaniowe klas niższych nie były oczywiście jednolite i ,arystokracja" robotnicza mieszkała zdecydowanie lepiej. W ich mieszkaniach oprócz pokoju była też zwykle kuchnia o powierzchni 12-15 m², w której toczyło się życie dzienne. Mieszkania te nierzadko posiadały toaletę. Korzystano z pralni, suszarni na pranie i własnej piwnicy. Zazwyczaj był tu też dostęp do wodociągu i bieżącej wody ${ }^{123}$.

Młody, samotny robotnik wydawał na mieszkanie $8 \%$ swoich dochodów, niby niewiele, ale pensja wystarczała ledwie na jedzenie. Mimo to było to dosyć, aby oszczędzić niewielką sumę na następną fazę życia w związku małżeńskim, chyba że praca przerywana była okresami bezrobocia. Po założeniu rodziny robotnicy nie posiadali zbyt wielu ruchomości: łóżko, kilka krzeseł, stół i szafa, czasem obraz i lustro. Ubogie było również wyposażenie kuchni ${ }^{124}$.

W mieszkaniach zamożniejszych robotników pojawiały się bieliźniarki, sofy, stoły z czterema krzesłami, możliwie jako komplet (u zwykłych robotników raczej nie występował). Na ścianach wisiały tanie reprodukcje obrazów, zwykle bardzo kiczowatych, o tematyce religijnej, jak anioły czy Madonny, landszafty i martwe natury z owocami, a także zdjęcia, np. dziecka z okazji konfirmacji, męża z wojska. Były to formy kulturowe naśladujące nieudolnie kulturę warstw wyższych, gdzie robotnicy starali się z jednej strony dowieść swych kompetencji

${ }^{121}$ A. von Saldern, Im Hause, zu Hause..., s. 206-211; B. Fuhrmann, W. Meteling, B. Rajkay, M. Weipert, Geschichte des Wohnens von Mittelalter..., s. 115; T. Nipperdey, Deutsche Geschichte $1866-1918 \ldots$, s. 142.

122 J. Kuczynski, Geschichte des Alltags..., s. 443.

${ }^{123}$ B. Fuhrmann, W. Meteling, B. Rajkay, M. Weipert, Geschichte des Wohnens von Mittelalter..., s. 214.

${ }^{124}$ J. Kuczynski, Geschichte des Alltags..., s. 437. 
kulturowych, z drugiej - odgrodzić się od jeszcze biedniejszych od siebie ${ }^{125}$. Biedni w miastach z konieczności starali się prowadzić gospodarkę domową możliwie autarkiczną. Bogatsi z biedniejszych wynajmowali w pobliżu domu ogródek działkowy z altaną, podobnie mieszkający w niewielkich mieszkaniach zakładowych, których było coraz więcej (przy zwolnieniu z pracy trzeba je było opuścićc ${ }^{126}$. Domki robotnicze występowały, ale częściej w Anglii, gdzie były popularną formą mieszkalnictwa wśród robotników. Takie domki znajdowały się zwykle poza miastem, z dala od zakładu pracy, co zwiększało koszty komunikacji miejskiej. Większe były też koszty utrzymania domu i zakupu żywności w podmiejskim sklepie. Mieszkańcy kamienic byli jednak uzależnieni od właściciela kamienicy, który posiadał nad nimi pewną władzę, co było dyskomfortem ${ }^{127}$.

W kamienicach czynszowych dużym problemem były liczne małe zakłady produkcyjne i rzemieślnicze nieposiadające odrębnej lokalizacji. W Berlinie w 1895 roku 95\% wszystkich zakładów stanowiły niewielkie firmy zatrudniające 51\% wszystkich pracowników (mniej niż 10 na zakład) i ulokowane w kamienicach. Nie wspomina się też, że mieszkania piwniczne były sposobem ominięcia zezwolenia na budowę określonej liczby pięter w danej kamienicy ${ }^{128}$.

Mimo wielu innowacji technicznych, odsetek służby domowej w zamożnych domach rósł. W Prusach w okresie $1810-1820$ służba stanowiła $0,9 \%$ populacji, a w $1880-1890$ - 3,2\% ${ }^{129}$. Jeszcze w 1895 roku na mieszczańską rodzinę przypadała jedna służąca, przy czym największy odsetek stanowiły one w wielkich miastach. W Berlinie w 1890 roku mniejszość z 79 tys. służących, bo tylko $7 \%$, stanowiły rodowite berlinianki. Aż 1/3 kobiet migrujących do Berlina zostawała służącymi. Służące spały często na poddaszu w nieogrzewanych klitkach liczących $6 \mathrm{~m}^{2}$, z niewielkim świetlikiem. Jeszcze w 1900 oku. tylko 10\% służących miało własny pokój, 38\% spało w pewnego rodzaju pawlaczach, do których wchodziło się po drabince, reszta w komórkach pod schodami. Służba cały czas podlegała karom gospodarza domu, tak w mieście, jak i na wsi, chociaż relacje między państwem a służbą były różne i złożone, co wynikało też z silnych

\footnotetext{
125 A. von Saldern, Im Hause, zu Hause..., s. 211-213.

126 Tamże, s. 214.

127 Tamże, s. 218; T. Nipperdey, Deutsche Geschichte 1866-1918..., s. 137.

${ }^{128}$ P.H. Feist, Geschichte der deutschen Kunst..., s. 270-271.

129 J. Kocka, Arbeitsverhältnisse und Arbeiterexistenen. Grundlagen der Klassenbildung im 19. Jahrhundert, Bonn 1990, s. 116.
} 
związków emocjonalnych łączących służących z dziećmi państwa ${ }^{130}$. Podobnie było w wypadku szlachty, która uważała ogromne różnice warunków mieszkaniowych służby i własnych za naturalne i oczywiste ${ }^{131}$.

Tkacze pracujący w domu nie mieli lepszych warunków mieszkaniowych. Spanie całej rodziny w jednym łóżku było tu sytuacją nie tyle normalną, co powszechną. Do spania wykorzystywano też specjalne skrzynie i ławy. W domach nie zawsze były krzesła, często zastępowały je drewniane kloce i ławy do siedzenia. Najnędzniej żyli jednak robotnicy rolni. Chałupy ich budowane były z gliny i pruskiego muru, z dachem krytym strzechą ${ }^{132}$.

Chaty chłopskie w rejencji opolskiej na Śląsku po 1850 roku budowane były już nie jak dotąd $\mathrm{z}$ drewna, ale raczej z cegły lub kamienia. Budownictwo drewniane i kryte strzechą wypierane było stopniowo, jednak powoli. Bliżej ośrodków miejskich łatwiej dostępna była papa, cegły, inne potrzebne materiały, dalej używano jeszcze nierzadko słomy na pokrycie dachu. Układ przestrzenny chałup często był tradycyjny, z częścią mieszkalną po jednej stronie sieni i gospodarczą po drugiej oraz kuchnią na przedłużeniu. Obok domu, często jako odgromnik, stawiano topolę czy leszczynę, a właściwe piorunochrony, mimo wynalezienia ich w XVIII wieku, dopiero w XX stuleciu ${ }^{133}$. W 1874 roku opis chłopskiej chaty wielkopolskiej wyglądał następująco: „Konie i bydło w mniejszych gospodarstwach stoją zazwyczaj razem w tym samym budynku (w którym ludzie mieszkają), połączonym wtedy sienią z zamieszkanym domem, z którym powierzchownie całość jedną przedstawia. W większych a zamożniejszych gospodarstwach dla wymienionego inwentarza istnieje osobna stajnia. Budynki przeważnie z gliny i drzewa, są zbyt niskie, ciemne i za szczupłe, w ogóle niewygodne ani dla mieszczącego się w nich inwentarza, ani dla mieszkańców"134. Przestrzeń mieszkalna u chłopów uwłaszczonych wynosiła ok. $100 \mathrm{~m}^{2}$, a 30-35 $\mathrm{m}^{2}$ u proletariatu wiejskiego $^{135}$. Parobcy na wsi spali często przy inwentarzu żywym, co dla Wielkopol-

${ }^{130}$ A. von Saldern, Im Hause, zu Hause..., s. 185-186; J. Kuczynski, Geschichte des Alltags..., s. 191-192; S. Parissien, Historia wnętrz..., s. 236.

${ }^{131}$ A. von Saldern, Im Hause, zu Hause..., s. 322.

132 Tamże, s. 283.

${ }^{133}$ W. Korzeniowska, Codzienność społeczności wsi rejencji opolskiej (1815-1914), Opole 1993, s. 47-50.

${ }^{134}$ Za: A. Glapa, Z zagadnień higieny, w: Kultura ludowa Wielkopolski, t. 2, red. J. Burszta, Poznań 1964, s. 373-374.

135 Tamże, s. 378. 
ski odnotowywał Oskar Kolberg w drugiej połowie XIX wieku. „Dziewki sypiają najczęściej razem w jednej izbie; zwykle każda z nich ma swoje łóżko zasłane słomą i grubym prześcieradłem; przykrywają się betami, tj. pierzynami, a pod głową mają po dwie poduszki z pierza. (...) Kładąc się spać i niewiasty i dzieci rozbierają się, lecz parobek często tylko buty zdejmie, odzienia zaś nie zdejmuje (czasem je tylko nieco rozepnie) szczególnie ci co sypiają w stajniach, oborach i owczarniach, przykrywają się derkami lub kocami”'136. Warunki sypialne na wsi były niezbyt korzystne od strony sanitarnej. Łóżko stało często w kuchni, gdzie było cieplej, a przestrzeń pod nim wykorzystywano do trzymania ziemniaków. W ostatnim ćwierćwieczu na wsi posługiwano się już piecami kaflowymi i naftowymi lampami, petrolowymi, jak je nazywano. Podłogi w końcu XIX wieku były jeszcze gliniane. Zamiatano je brzozową miotłą i posypywano białym albo żółtym piaskiem. Zdarzały się też podłogi drewniane, myte zwykle raz na tydzień i również wysypywane białym piaskiem. Szorowano je wiechciami słomy i wiązkami perzu. Ściany jedynie bielono, używając do tego wapna ${ }^{137}$.

O wnętrzu chaty chłopskiej włościanina wielkopolskiego pisał Oskar Kolberg: „Wnętrze domu wieśniaka wielkopolskiego porządniej i bogaciej się przedstawia niż wnętrze mieszkania wielu stron Polski. Izba wapnem zwykle wybielona, dość schludnie bywa utrzymana, lubo rzadko kiedy wielkiego jest rozmiaru" ${ }^{138}$. Trzeba jednak pamiętać, że i na Zachodzie życie chłopskie nie było wtedy zbyt sielankowe. Dla Francji czytamy charakterystyki nie mniej przygnębiające niż dla zaboru pruskiego: „te nędzne rudery, wilgotne i źle oświetlone, niewłaściwie urządzone, gdzie gnieżdżą się zwierzęta i ludzie" ${ }^{\prime 39}$.

\section{Bibliografia}

Baranowski B., Wyposażenie wnętrz, w: Historia kultury materialnej Polski, t. 6, red.

B. Baranowski, Wrocław 1979.

Benjamin W., Berlińskie dzieciństwo na przełomie wieków, Warszawa 2010.

Benjamin W., Pasaże, Kraków 2005

Benjamin W., Ulica jednokierunkowa, Warszawa 2011.

\footnotetext{
136 Tamże, s. 381

${ }^{137}$ Tamże, s. 382-383, 386-387.

138 Tamże, s. 389.

${ }^{139}$ M. Perrot, Sposoby zamieszkiwania..., s. 362-363.
} 
Born K.E., Preußen im deutschen Kaiserreich 1871-1918, w: Handbuch der preußischen Geschichte, Bd. 3, hrsg. v. W. Neugebauer, Berlin-New York 2001.

Burdziński C., Wielkopolska spółdzielczość mieszkaniowa w latach 1890-1945, w: 90 lat spółdzielczości mieszkaniowej w Polsce (1890-1980), red. J. Topolski, Poznań 1982.

Corrodi M., Von Küchen und unfeinem Gerüchen. Auf dem Weg zu einer neuen Wohnkultur zwischen Gründerzeit und zweitem Weltkrieg, w: Die Küche. Lebenswelt, Nutzung, Perspektiven, hrsg. v. K. Spechtenhauser, Birkhäuser, Basel i in. 2006.

Craemer R., Der Kampf um die Volksordnung. Von den preußischen Volkspolitik, Hamburg 1933.

Eco U., Historia Brzydoty, Poznań 2007.

Engels F., W kwestii mieszkaniowej, w: tegoż, Dzieła wybrane, t. 1, Warszawa 1949.

Erbe M., Berlin im Kaiserreich (1871-1918), w: Geschichte Berlins, Bd. 2, hrsg. v. W. Ribbe, Berlin 2002.

Feist P.H., Geschichte der deutschen Kunst 1848-1890, Leipzig 1987.

Frevert U., Krankheit als politisches Problem. Soziale Unterschichten in Preußen zwischen medizinischer Polizei und staatlicher Sozialversicherung, Göttingen 1984.

Fuchs C.J., Wohnungsfrage, w: Die Entwicklung der deutschen Volkswirtschaftslehre im 19 Jahrhundert, T. 1, Leipzig 1908.

Fuhrmann B., Meteling W., Rajkay B., Weipert M., Geschichte des Wohnens von Mittelalter bis heute, Darmstadt 2008.

Gause F., Die Geschichte der Stadt Königsberg, Köln-Graz 1968.

Glapa A., Z zagadnień higieny, w: Kultura ludowa Wielkopolski, t. 2, red. J. Burszta, Poznań 1964.

Hausen K., Postęp techniczny, a praca kobiet $w$ XIX w. Maszyna do szycia $w$ świetle historii społecznej, w: tejże, Porzadek płci. Studia historyczne, Warszawa 2010.

Hauser A., Społeczna historia sztuki i literatury, t. 2, Warszawa 1974.

Hubbard W.H., Familiengeschichte. Materialien zu deutschen Familie seit dem Ende des 18. Jahrhunderts, München 1983.

Jedlicki J., Świat zwyrodniały. Lęki i wyroki krytyków nowoczesności, Warszawa 2000.

Kocka J., Arbeitsverhältnisse und Arbeiterexistenen. Grundlagen der Klassenbildung im 19. Jahrhundert, Bonn 1990.

Korzeniowska W., Codzienność społeczności wsi rejencji opolskiej (1815-1914), Opole 1993.

Kuczynski J., Geschichte des Alltags des deutschen Volkes, Bd. 4, Berlin 1982.

Kukuryka S., Dorobek polskiej spółdzielczości mieszkaniowej, w: 90 lat spółdzielczości mieszkaniowej w Polsce (1890-1980), red. J. Topolski, Poznań 1982.

Lindmayer J., Bytów w okresie przemian ustrojowo-prawnych i społeczno-gospodarczych Prus (1815-1918), w: Historia Bytowa, red. Z. Szultka, Bytów 1998.

Lottmann H.R., Juliusz Verne, Warszawa 1999. 
Maćkowiak Z., Popow T., Klasycy marksizmu o kwestii mieszkaniowej, w: 90 lat spótdzielczości mieszkaniowej w Polsce (1890-1980), red. J. Topolski, Poznań 1982.

Makowski E., Ruch robotniczy w Wielkopolsce. Zarys dziejów do roku 1981, Poznań 1984.

Matusik P., „,Nadeszła epoka przejścia”. Nowoczesność w piśmiennictwie katolickim poznańskiego 1836 - 1871, Poznań 2011.

Matzerath H., Urbanisierung in Preußen 1815-1914, Stuttgart 1985.

Mumford L., Die Stadt. Geschichte und Ausblick, Köln 1963.

Nipperdey T., Deutsche Geschichte 1866-1918, München 1991.

Ostrowska-Kłębowska Z., Skuratowicz J., Architektura i budownictwo, w: Dzieje Poznania, t. 2: 1793-1918, red. J. Topolski, L. Trzeciakowski, Warszawa-Poznań 1994.

Parissien S., Historia wnętrz. Dom od roku 1700, Warszawa 2010.

Perrot M., Sposoby zamieszkiwania, w: tejże, Historia życia prywatnego, t. 4, Wrocław 1999.

Reulecke J., Die Mobilisierung der „Kräfte und Kapitale“ der Wandel der Lebensverhältnisse im Gefolge von Industrialisierung und Verstadterung, w: Geschichte des Wohnens, Bd. 3, hrsg. v. J. Reulecke, Stuttgart 1997.

Ritter G.A., Der Sozialstaat. Etstehung und Entwicklung im internationalen Verleich, München 1991.

Rybczyński W., Dom. Krótka historia idei, Gdańsk-Warszawa 1996.

Saldern A. von, Im Hause, zu Hause. Wohnen im Spannungsfeld von Gegebenheiten und Aneignungen, w: Geschichte des Wohnens, Bd. 3, hrsg. v. J. Reulecke, Stuttgart 1997.

Stażewski M., Dzieje Lęborka 1815-1918, w: Dzieje Lęborka, red. J. Borzyszkowski, Lębork-Gdańsk 2009.

Tilly R.H., Vom Zollverein zum Industriestaat. Die wirtschaftlich-soziale Entwicklung Deutschlands 1834 bis 1914, München 1990.

Trzeciakowski L., Warunki kształtowania się spółdzielczości polskiej w pod zaborem pruskim, w: 90 lat spółdzielczości mieszkaniowej w Polsce (1890-1980), red. J. Topolski, Poznań 1982.

Turek-Kwiatkowska L., Życie codzienne w Szczecinie w latach 1800-1939, Szczecin 2012.

Vigarello G., Historia zdrowia i choroby, Warszawa 1997.

Weber M., Gospodarka i społeczeństwo, Warszawa 2002.

Wehler H.-U., Deutsche Gesellschaftsgeschichte 1849-1914, Bd. 3, München 1995.

Wierzchosławski S., Orzeł czarny i orzet biały. Problemy modernizacji społeczeństwa polskiego prowincji Prusy Zachodnie w XIX i na początku XX w., Olsztyn 2011.

Wietog J., Der Wohnungsstandard der Unterschichten in Berlin, w: Arbeiterexistenz im 19. Jahrhundert. Lebensstandard und Lebensgestaltung deutscher Arbeiter und Handwerker, hrsg. v. W. Conze, U. Engelhardt, Stuttgart 1981. 
Wischermann C., Wohnen in Hamburg vor dem Ersten Weltkrieg, Münster 1983.

Włodarczyk E., Rozwój przestrzenny i demograficzny miasta, w: Dzieje Szczecina 18061945, red. B. Wachowiak, Szczecin 1994.

Zimmermann C., Wohnen als sozialpolitische Herausforderung. Reformerisches Engagement und öffentliche Aufgaben, w: Geschichte des Wohnens, Bd. 3, hrsg. v. J. Reulecke, Stuttgart 1997.

\title{
Abstrakt
}

Własny dach nad głową w epoce industrializacji i urbanizacji w Prusach po 1871 roku był marzeniem dla wielu nieosiągalnym, szczególnie dla chłopów, robotników rolnych, dniówkowych, fabrycznych, rzemieślników, uboższych pracowników umysłowych i niższych urzędników. Na sposób zamieszkiwania wielki wpływ miało też rozszerzające się wraz z industrializacją i wielkim napływem ludności do miast zjawisko ubożenia niższych warstw miejskich, do którego, oprócz złych warunków mieszkaniowych, zaliczało się też nieodpowiednie wyżywienie i zaspokojenie innych potrzeb życiowych. XIX stulecie wytworzyło jednak mieszczańskie kulturowe wyobrażenie przyjaznego domu, będącego obszarem odpoczynku wobec zagrożeń świata, które stało się fundamentem dzisiejszych masowych wyobrażeń. Wówczas wszakże tylko niewielki odsetek owo przyjazne oparcie otrzymał, przytłaczająca większość dom traktowała jedynie jako sypialnię.

\section{'A Craze for a Flat', or the Flat and its Surroundings in Prussia IN THE YeARS 1871-1818}

\begin{abstract}
To have a roof over one's head was an unattainable dream for many people in Prussia after 1871 in the era of industrialisation and urbanisation. The groups for whom that problem was the most acute were: peasants, agricultural labourers, labourers paid per day, factory workers, craftsmen, poorer white collar workers and low-ranking officials. The dwelling forms were strongly influenced by a growing phenomenon of pauperisation of lower urban classes, industrialisation, an enormous inflow of people into towns, inappropriate nutrition and an inadequate satisfaction of other basic needs. Yet, it was in the $19^{\text {th }}$ century when the bourgeois cultural image of a friendly home was constructed, which has become a space of rest against the threats of the outside world and a basis for the present-day mass concept. But, at that time only members a tiny part of the society managed to get this friendly retreat; for the overwhelming majority their homes were just sleeping places.
\end{abstract}

